\title{
Foundation Giving and Economics Research Productivity at HBCUs: Empirical Evidence from the Koch Foundation
}

\author{
Shuyi Deng ${ }^{1} \cdot$ Yufeng Lai $^{2} \cdot$ Samuel L. Myers Jr. ${ }^{1} \cdot \operatorname{Man} X \mathbf{X u}^{1}$ \\ Received: 30 November 2019 / Revised: 5 July 2020 / Accepted: 8 July 2020 / Published online: 11 August 2020 \\ (C) The Author(s) 2020
}

\begin{abstract}
Existing research on funding disparities between historically black colleges and universities (HBCUs) and non-HBCUs primarily focuses on government funding and pays little attention to foundation giving. This paper helps to fill this gap by examining the effects of funding by the Charles Koch Foundation - a major funder of economics research in the USA — on the economics research productivity at HBCUs. Using data from the foundation's tax forms, the Integrated Postsecondary Education Data System (IPEDS), and Scopus, this paper examines factors that explain the foundation's grant results and how the foundation's money affects economics research productivity at HBCUs. The paper estimates the effects of Koch funding on three different measures of HBCU productivity: number of publications, citations, and publications in top economics journals. We report ordinary least squares, two-step generalized linear model, and Poisson results that show little or no impact from (a) recipiency of a Koch grant, (b) the total amount of grant dollars, or (c) the average amount of grant dollars on research productivity. We also obtain event study and difference-in-differences estimates of the effects of Koch grants to HBCUs on publications and publications per faculty member and again find no statistically significant impacts. The evidence obtained - consistent across different model specifications and estimation techniques - does not support the hypothesis that Koch's funding to HBCUs is primarily geared towards enhancing the research productivity of these colleges and universities. The paper discusses alternative explanations for the Charles Koch Foundation's targeting strategy and its involvement with particular HBCUs.
\end{abstract}

Keywords Foundation giving $\cdot$ Higher education $\cdot$ Research productivity $\cdot \mathrm{HBCU} \cdot$ Charles Koch Foundation

JEL Classifications I23 $\cdot$ J15 $\cdot$ D63

\section{Introduction}

Historically black colleges and universities (HBCUs) have produced many of the pioneering African American

\footnotetext{
${ }^{1}$ An HBCU, as defined by the Higher Education Act of 1965, is "any historical black college or university that was established prior to 1964 , whose mission was and is the education of black Americans." Distinguished black economists who graduated from HBCUs include Bernard Andersonthe first black tenured faculty member at the Wharton School—and Samuel Z. Westerfield, Jr., former Dean of the School of Business at Atlanta University.
}

Shuyi Deng

dengx413@umn.edu

1 Hubert H. Humphrey School of Public Affairs, University of Minnesota, Minneapolis, MN, USA

2 Department of Applied Economics, 231 Ruttan Hall, 1994 Buford, Avenue, St. Paul, MN 55108, USA economists in America (Myers 2017). ${ }^{1}$ Most HBCUs were established and developed under the "separate but equal" doctrine of Plessy v. Ferguson. Even though the US Supreme Court rejected the doctrine in 1954 with the Brown v. Board of Education decision, and equal treatment regardless of race, color, or nationality was written into the Civil Rights Act of 1964, it is widely believed that HBCUs still confront challenges in such aspects as funding and student and faculty recruitment when compared with traditionally white institutions (TWIs) (Betsey 2007). Given the social value of HBCUs in increasing human capital stock (Price et al. 2011) and promoting social integration (Morse et al. 1996), it is essential to address the challenges HBCUs face.

Existing studies have confirmed budgetary disparities between HBCUs and TWIs and the dangers of such disparities. Toldson (2016) showed that in 2014, eighty-nine 4-year HBCUs collectively received $\$ 1.2$ billion in grants and contracts from federal, state, and local governments as well as 
private foundations, while John Hopkins University alone received $\$ 1.6$ billion. Sav (2010) decomposed the differences in state funding to 33 state-supported HBCUs and 211 TWIs and found that $12.5 \%$ of the difference was due to different treatment of HBCUs and TWIs instead of institutional characteristics such as tuition, private endowments, federal grants and contracts, auxiliary enterprise revenue, and physical plant assets. Dougal et al. (2019), on the other hand, found that HBCUs were discriminated in the bond market, especially in the Deep South, where racial animus remains the most severe.

Gasman et al. (2007) pointed out the danger of inadequate finances exacerbating HBCUs' problems with academic freedom and shared governance, as they believed that more significant violation of these principles at HBCUs was due to constant financial crises that made HBCUs more vulnerable to funding with strings attached. Later, under the circumstances of the 2008 economic crisis, Gasman (2009) argued that HBCUs had limited room to deal with the crisis as they served a student population that was disproportionately low income and trying to afford higher tuition at schools with smaller endowments because of the history of segregation.

More recent evidence confirms that HBCUs' disadvantages in receiving funding were exacerbated during periods of economic downturn. Ortega and Swinton (2018) examined state appropriations over 29 years and found that HBCUs received less funding than other institutions when controlling for school characteristics. Additionally, such funding disparities were enlarged when there was an economic downturn.

Current research on funding disparities between HBCUs and TWIs primarily focuses on government funding and pays little attention to foundation giving to HBCUs. The reasons might be twofold. On the one hand, foundation giving comprises a small part of the overall revenues of HBCUs compared with government funding. According to their revenue data reported to the Integrated Postsecondary Education Data System (IPEDS), gifts, which include income from private donors, make up $0.6 \%$ of HBCUs' total revenue in 2018, while state appropriations make up about $30 \%$. On the other hand, there is a wide belief in philanthropy for supporting the common good of higher education (Murray 2013). However, broader research on university funding has found that funding organizations with political agendas, or venture philanthropists (Kumashiro et al. 2012), take advantage of the harsh economic realities of higher education institutions to influence teaching and research activities (Boyce 2013). As mentioned earlier, HBCUs are more vulnerable to such philanthropists due to the financial constraints they face (Gasman et al. 2007; Gasman 2009). In this sense, examining the effects of foundation giving on HBCUs is of critical importance, even though this type of revenue makes up a small portion of HBCUs' total revenues.

Research has found that the National Science Foundation (NSF) research support to black economists at HBCUs who have never been funded by the NSF increases their research productivity substantially (Price 2007). This paper joins this line of research to fill the gap in the current literature by focusing on another type of foundation giving. This paper studies foundation giving to HBCUs and its impacts on HBCUs' economics research output through a case of one of the most controversial research funders in the USA: the Charles Koch Foundation. The paper proceeds as follows. The next section introduces the case of the Charles Koch Foundation and the current debates on its involvement with higher education institutions. The third section presents the research questions and the data used to answer them. The fourth section discusses the empirical models and results. The last section concludes the paper by discussing limitations and direction for future studies.

\section{The Case: Charles Koch Foundation}

Discussion about foundations' involvement in universities and their impact on academic independence has accelerated in recent years with the release of several agreements signed between 2003 and 2011 by George Mason University and some of its benefactors. These agreements contained language that provided donors with opportunities to weigh in on faculty hiring, research topics of sponsored faculty, and curriculum development (Why George Mason's 2018). The Charles Koch Foundation was put in the spotlight in such discussions as George Mason University is its largest grant recipient. According to the foundation's released tax forms, from 1988 to 2016, the Charles Koch Foundation gave George Mason University more than $\$ 100$ million through 21 grants, comprising about $57 \%$ of its total giving to colleges and universities in the USA during that period.

Billionaire Charles Koch founded the Charles Koch Foundation in 1980. The foundation endorses philosophies of a free and open society, market-based management, and principled entrepreneurship. Richard Fink, the former president of the Charles Koch Foundation, developed a three-step strategy for "the structure of social change" to pursue the foundation's goals. Under this strategy, colleges and universities are viewed as the primary sites to produce ideas, which then will be promoted by think tank organizations and implemented by activists (Fink 2012).

Funding research at colleges and universities was the Charles Koch Foundation's first step to promote social change of the type the foundation supported. To date, the foundation has supported research and education at more than 300 colleges and universities in the USA (List of supported colleges 2018). The main areas of funding include criminal justice and policing reform, free speech, foreign policy, removing barriers to economic opportunity, technology and innovation, and K-12 education. Although the foundation explicitly states that they "reject racism, sexism, and any discrimination that impedes equal 
rights" (About us n.d.), it remains one of the most controversial academic donors because of its founder's public support for conservative political causes and candidates. Charles Koch supports many free market-oriented educational organizations, including the Institute for Humane Studies, the Ayn Rand Institute, the Cato Institute, and the Mercatus Center at George Mason University. These efforts are designed to affect public views and academic perspectives on economics and the importance of free and unfettered markets.

Although the Charles Koch Foundation has reiterated that they respect recipient institutions' autonomy and independence (Hardin 2018), there remains a concern about politically motivated donors like the Charles Koch Foundation. The strings attached to such grants are believed to impede shared governance and academic freedom at universities, which are two of the fundamental and essential principles of higher education to support colleges and universities in serving the public interest, as opposed to the narrow special interests of big corporations, wealthy donors, and/or powerful politicians (Fichtenbaum 2018).

HBCUs are also concerned about grants from the Charles Koch Foundation because the libertarian and conservative stance of the foundation and its founder may be at odds with the best interests of African American scholars and students. The Charles Koch Foundation's support of education and research at HBCUs has exploded. According to the foundation's tax forms, it has provided small grants directly to HBCUs since 2010. However, in recent years, the foundation has begun to give large gifts indirectly to major HBCU funding organizations. In 2014, the Charles Koch Foundation and Koch Industries pledged \$25 million to the United Negro College Fund (UNCF) for student scholarships and other aid to HBCUs, which was the fifth-largest donation the UNCF has received in its seven decades of existence (Mock 2014). In early 2017, the Koch Foundation gave \$25.6 million to the Thurgood Marshall College Fund, an emergent fund that supports HBCUs to launch the Center for Advancing Opportunity to research education, criminal justice, and entrepreneurship in fragile communities (Thurgood Marshall College Fund launches 2017).

Suspicions about the intentions of the Charles Koch Foundation in supporting HBCUs abound. Ralph Wilson, a co-founder of an activist group called UnKoch My Campus, asserted that "Koch's presence in higher education is not educational, but strictly political in purpose" (Anderson 2017). A quote supports such accusations from Charles Koch at a 1974 gathering of the Institute for Humane Studies, in which he said, "educational programs are superior to political action, and support of talented free-market scholars is preferable to mass advertising" (Kotch 2018). Marybeth Gasman, former director of the Center for Minority Serving Institutions at the University of Pennsylvania, expressed the same suspicion by pointing out that the Koch brothers have given vast amounts of money to Tea Party candidates who oppose many policies, initiatives, and laws that empower African Americans (Gasman 2014). The Koch Foundation has defended its giving by noting that their gifts help alleviate funding shortfalls in higher education. Critics have counter-argued that Koch supports the American Legislative Exchange Council's heavy promotion of privatizing college education and then supplies privately financed scholarships when it actually happens (Mock 2014).

\section{Research Questions, Data, and Measures}

The ongoing discussion about the Charles Koch Foundation and the more general discussion about the impact of politically motivated foundations on higher education remain confined to media accounts and popular publications. So far, there is little empirical evidence to address this critical topic. This paper tries to fill this gap by providing an empirical analysis of the impacts of Charles Koch Foundation grants on its college grantees.

The Charles Koch Foundation is very specific that the purpose of its giving to colleges and universities is to "have an impact on the world, not produce research that sits on a shelf." They want the research they fund "to be read, scrutinized, debated, and consulted so it can inform dialogue and lead to solutions to the most pressing issues." (The higher education grant n.d.) Therefore, we focus on publications and citations resulting from direct research grants to colleges and universities, a measure of academic research productivity. Since the focus is on "research to be read, scrutinized, debated, and consulted...," we exclude grants such as the UNCF/Koch program that focus on training undergraduate entrepreneurs. Our focus is on economics publications because the underlying philosophy of the Koch Foundation is the promotion of free markets. Empirical evidence shows significant disparities in economics research outputs between HBCUs and nonHBCUs at both the departmental level (Agesa et al. 2000) and individual level (Agesa et al. 2001, 2002, 2005).

This paper addresses two questions: (1) What are the factors that explain the Charles Koch Foundation's grant results? And (2) Does funding from the Charles Koch Foundation improve economics productivity at HBCUs? The first question aims to provide empirical evidence of the Charles Koch Foundation's targeting strategy that has been widely discussed in media accounts and popular publications. If their targeting strategy is confirmed, we turn to the second question to examine the effects of Charles Koch Foundation grants on HBCUs, given the fact that HBCUs are not its traditional target but have increasingly received money from the foundation.

The data to answer these two questions was compiled from three sources. First, we compiled a list of college and university grantees and the grants they received from the released tax 
forms of the Charles Koch Foundation from 1998 to 2016. During this period, the Charles Koch Foundation gave 177 million dollars through 1491 grants to 414 US colleges and universities to support their research and education. Figure 1 presents the trends in Charles Koch Foundation grants to institutions of higher education in the USA. Since 2008, both the number of grants and the amount of grants from the Charles Koch Foundation to all colleges and universities have increased dramatically. It was during this period of rapid expansion that the foundation started to fund HBCUs. Since 2010 , the Koch Foundation has given about $\$ 191,000$ through 18 grants to nine HBCUs in the USA. The grants to HBCUs account for $0.1 \%$ of the total dollar amount of grants to colleges and universities, and $1.2 \%$ of the total number of grants awarded by the foundation.

Second, the characteristics of all colleges and universities in the USA were collected from the Integrated Postsecondary Education Data System (IPEDS). For this dataset, we excluded less-than-2-year institutions such as cosmetology and trade schools as well as private, for-profit colleges, and universities. All the 101 HBCUs in IPEDS fall into the category of 2-year or 4-year colleges and universities. Excluding institutions that do not report information to IPEDS resulted in a total of 411 grantee colleges and universities, nine of which are HBCUs.

Figures 2, 3, and 4 present the distribution of the probability of receiving a grant from the Charles Koch Foundation, the total dollar amount of grants, and the average amount per grant across institutional characteristics. Figure 2 shows that non-HBCUs are slightly more likely to receive Charles Koch Foundation grants than are HBCUs. While public and private, not-for-profit institutions are similarly likely to receive grants, large universities are much more likely to be awarded a grant by the Charles Koch Foundation compared with small colleges. Figure 3 shows the average total dollar amount of grants across institutional characteristics for recipient institutions. Non-HBCUs receive nearly six times as much in grants as do HBCUs. The average total dollar amount granted to public institutions is more than twice as much as private, not-forprofit institutions, and large universities receive more than six times as much as small colleges. Figure 4 shows the difference in the average amount per grant. The differences are significant: For those who are actually awarded grants by the Charles Koch Foundation, the average amount per grant for non-HBUCs is 20 times greater than HBCUs. The amount for public institutions is about five times as much as private, notfor-profit institutions and is about 12 times as much for large universities as small colleges.

Third, productivity data were extracted from Scopus, the largest abstract and citation database of peer-reviewed literature. For this dataset, we restricted productivity to the subfield of economics, econometrics, and finance, which includes publications in economics journals and business journals regardless of whether the authors are affiliated with economics departments. This choice accounts for the fact that economics faculty often are housed in multidisciplinary departments, especially for those at HBCUs (Agesa et al. 1998).

Although tax forms do not specify the departments to which Charles Koch Foundation grants were awarded, the foundation invests heavily and predominately in economics-related areas. Over the past 3 years, the Charles Koch Foundation has awarded substantial grants to several universities to support economics research. In 2017, it gave \$3.4 million to the Texas A\&M Foundation to support the Private Enterprise Research Center (PERC) at Texas A\&M University (Texas A\&M Foundation Staff 2017). In early 2018, the economics department at George Mason University received a \$5 million grant to support new faculty hiring (\$5 million gift 2018). In the summer of 2018, the Orange County campus of Chapman University in California also received a $\$ 5$ million grant to fund a program in "Humanomics," which the university defines as "reintegrating the study of the humanities and economics" (Roosevelt 2018). More recently, the Center for the History of Political Economy at Duke University received a \$5 million grant from the Foundation to hire new faculty and expand relationships with students (Cho 2018).

As for measures of productivity, this paper focuses on institutional productivity, given the fact that the Charles Koch Foundation's tax forms only release grant information at the institution level. The current literature on research productivity falls into three types: individual productivity of faculty, departmental productivity, and institutional productivity. While most of the literature in this field studies individual productivity, measures of research productivity remain relatively consistent across different levels. In his studies on the research outputs of Australian university economics departments, Harris (1990) outlines four related but distinct ways of evaluating research performance: quantity - the number of articles or pages produced; impact-generally measured by the number of citations; and quality and importance-two other measures that are more valueladen. The quantity and impact measures are widely used to assess research productivity in different fields around the world. Depending on the specific research questions, these two measures are usually scaled by co-authorship or by faculty size. The impact factor that Eugene Garfield developed to assess the journals in the Science Citation Index (Garfield 1976) is widely adopted to measure the quality and importance of research outputs. With the development of the knowledge economy in recent years, the number and quality of patents have become accessible measures of research productivity, especially in applied fields.

In consideration of the current literature on research productivity and the expectations of the Charles Koch Foundation on the research they fund, we measure research productivity in 
Fig. 1 Number and amount of Charles Koch Foundation grants to colleges and universities in the USA, 1998-2016. Source: 990 federal tax forms of the Charles Koch Foundation

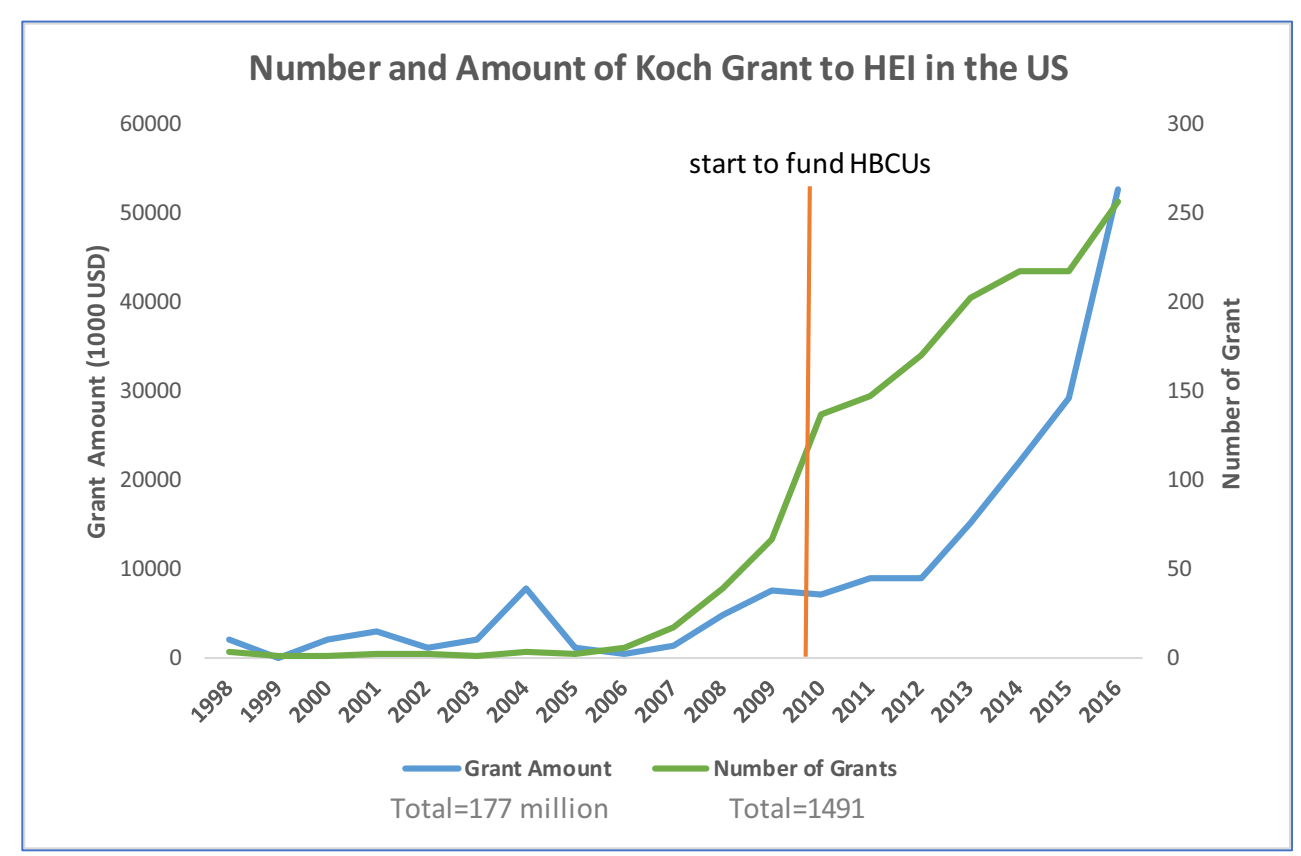

three different but related ways: (1) the number of economics publications per faculty member; (2) the number of citations of published economics papers per faculty member; and (3) the probability of publishing in one of the top 30 economics journals (Appendix Table 13).

\section{Empirical Models and Results}

\section{Charles Koch Foundation Granting Results}

One of the concerns about the Charles Koch Foundation's involvement in higher education is that they target specific
Fig. 2 Probability of receiving a grant, by institutional characteristics

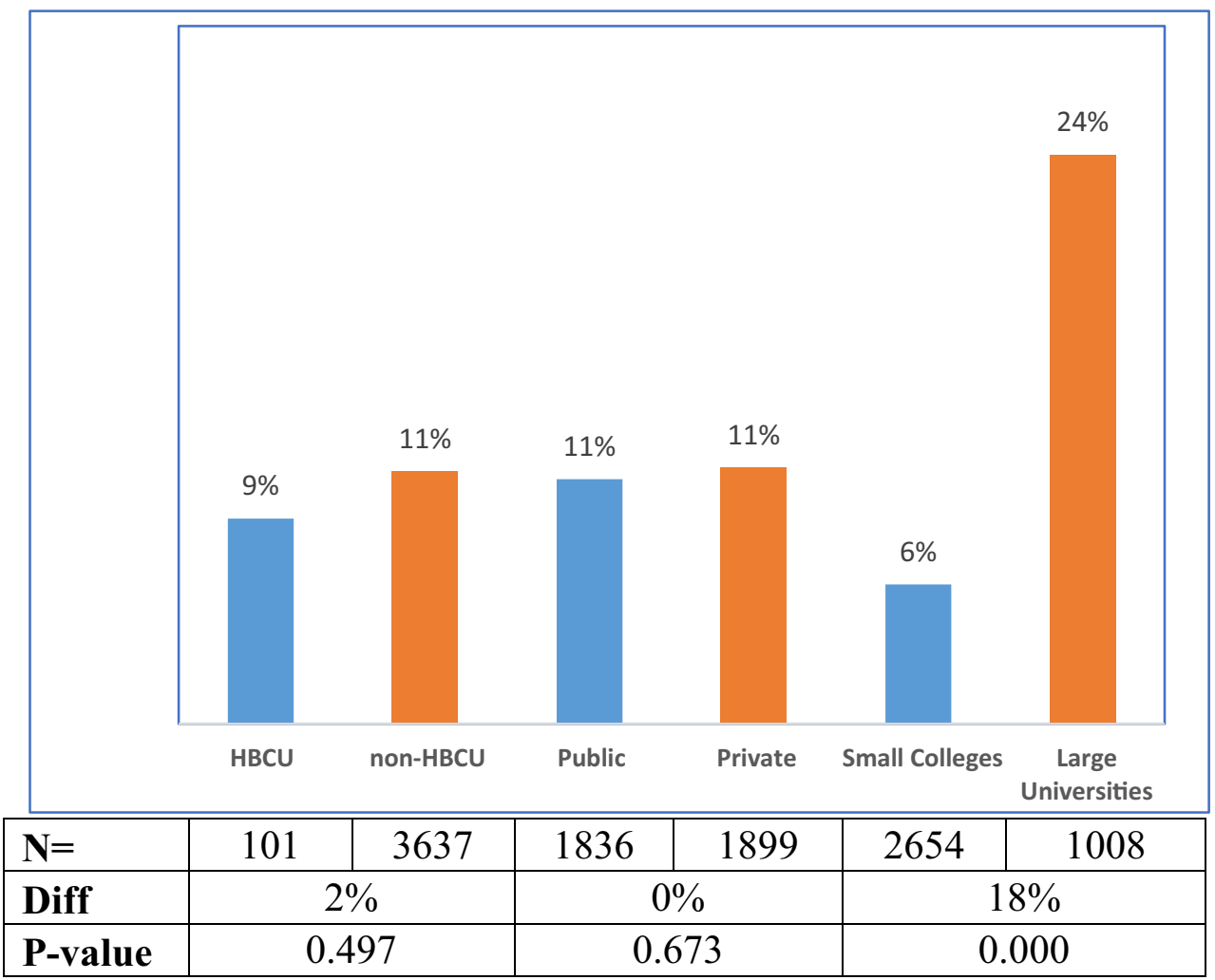




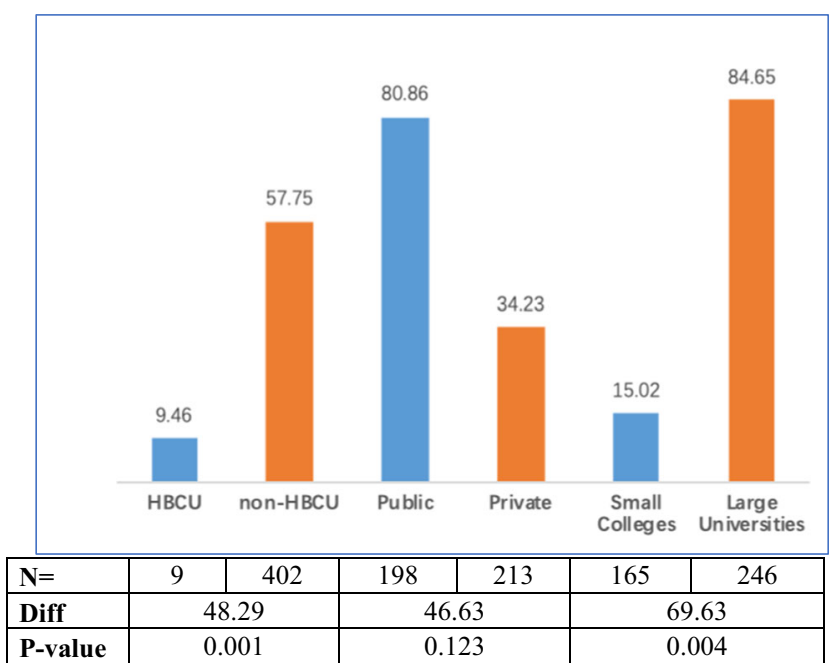

Fig. 3 Mean total dollar amount of grants (in thousands of dollars), by institutional characteristics

types of colleges and universities. The motivation of this section is to find out what factors explain an institution's grant results in terms of the probability of receiving a grant from the Foundation, the total dollar amount of grants awarded, and the average amount per grant awarded.

We use the data on institutional characteristics collected from IPEDS, excluding less-than-2-year institutions and private for-profit institutions. We then use the grants data from the foundation's tax forms to code each institution's grant results from the Charles Koch Foundation through a dummy variable indicating whether an institution received a grant between 1998 and 2016.

The probability of getting a grant is estimated with a logit model:

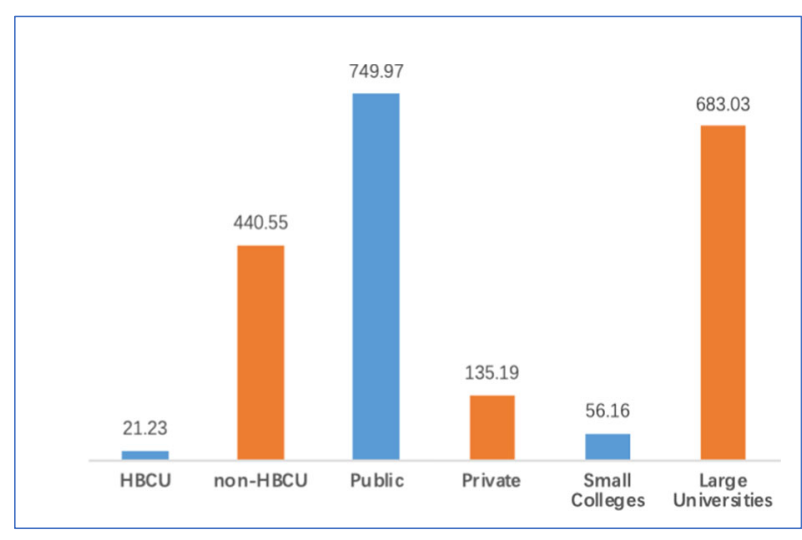

\begin{tabular}{|l|c|c|c|c|c|c|}
\hline $\mathbf{N}=$ & 9 & 402 & 198 & 213 & 165 & 246 \\
\hline Diff & \multicolumn{2}{|c|}{419.32} & \multicolumn{2}{|c|}{614.78} & 626.86 \\
\hline P-value & \multicolumn{2}{|c|}{0.095} & \multicolumn{2}{|c|}{0.228} & \multicolumn{2}{c|}{0.127} \\
\hline
\end{tabular}

Fig. 4 Average amount per grant (in thousands of dollars), by institutional characteristics $\ln \left(\frac{\operatorname{Pr}\left(Y_{i t}=1 \mid X_{i t}\right)}{\operatorname{Pr}\left(Y_{i t}=0 \mid X_{i t}\right)}\right)=\beta_{0}+\beta_{1} \mathrm{HBCU}_{i}+\sum_{i} \beta_{i} X_{i t}+\alpha_{i}+\epsilon_{i t}$

where $Y_{i t}$ is a dichotomous variable that denotes whether institution $i$ received a grant from the Charles Koch Foundation in year $t ; \mathrm{HBCU}_{i}$ is a dummy variable indicating an $\mathrm{HBCU}$ institution or not; and $X_{i t}$ denotes a vector containing three sets of control variables. We control for a first set of variables, including tuition and fees, government funding, total revenue, and control (public/private) of institution. The second set of covariates includes indicators of successful knowledge producers. In their studies on the determinants of research productivity in higher education, Dundar and Lewis (1998) summarize the institutional attributes associated with research productivity, which include size, control by the private sector, revenue, technology and library resources, workload policies, and availability of star faculty. Limited by data availability in IPEDS, in the second set of covariates, we control for size, graduation rate, research expenses, and whether an institution awards $\mathrm{PhD}$ degrees. With a particular interest in HBCUs, the third set of covariates including the percentage of black enrollment and the percentage of degrees awarded to blacks is also accounted for; $\alpha_{i}$ denotes state fixed effects to control for variances between states that affect revenues of HBCUs in the same way over the years.

Table 1 reports the defintions and measurements of variables used to estimate the Charles Koch Foundation grant results.

Table 2 shows the results of the estimations. Note that the number of observations drops due to missing values for independent variables. The results confirm that signs of high productivity are positively associated with the probability of receiving a grant. Large, PhD-granting institutions with higher graduation rates and more research expenses per faculty member are more likely to receive a grant from the Charles Koch Foundation. On the other hand, institutions with a higher proportion of revenues from government funding are less likely to receive a Charles Koch Foundation grant. Private institutions, which usually have more room to increase tuition and fees during financial difficulties, are also less likely to be awarded a grant.

With all the factors as mentioned earlier controlled, HBCUs are less likely to receive a grant from the Charles Koch Foundation. As model (2) in Table 2 indicates, the probability of an HBCU receiving a grant is $42 \%$ (exponentiation of -0.875 ) of that of a non-HBCU. However, selection bias might be of concern before we conclude that HBCUs are disadvantaged in receiving a Charles Koch Foundation grant. Because the current data has no information on who applied for one of the 
Table 1 Covariate definitions for grant result estimations

\begin{tabular}{ll}
\hline Variable & Description \\
\hline HBCU & A dummy to indicate whether an institution is an HBCU \\
Graduation rate & Graduation rate of institutions reported to IPEDS \\
Private institution & A dummy to indicate public or private institutions \\
$\%$ Government funding & Revenues from federal, state, and local government divided by total revenue \\
$\begin{array}{l}\text { Research expense per } \\
\text { faculty }\end{array}$ & Total research expenses divided by the number of full-time faculty members \\
Tuition per student & Total revenue from tuition divided by the total number of students \\
$\begin{array}{l}\text { Large university } \\
\text { Award PhD degrees }\end{array}$ & A dummy to indicate large institutions with a total enrollment of more than 5000 \\
$\%$ Degrees awarded to & A dummy to indicate institutions that award PhD degrees \\
blacks & Number of degrees awarded to blacks divided by the total number of degrees \\
\% Blacks enrolled & awarded
\end{tabular}

foundation's grants, the observed difference in the probabilities of receiving a grant between HBCUs and non-
HBCUs might be due to discrimination imposed on HBCUs by the foundation, or due to the possibility that
Table 2 Maximum likelihood estimates of coefficients in logistic models of the probability of Koch Foundation grant

\begin{tabular}{|c|c|c|c|c|}
\hline & (1) & $(2)$ & (3) & (4) \\
\hline $\mathrm{HBCU}$ & $\begin{array}{l}-1.273^{* * *} \\
(0.242)\end{array}$ & $\begin{array}{l}-0.875^{* * *} \\
(0.256)\end{array}$ & $\begin{array}{l}-0.169 \\
(0.478)\end{array}$ & $\begin{array}{l}-0.729 * \\
(0.442)\end{array}$ \\
\hline Graduation rate & & $\begin{array}{l}0.0189 * * * \\
(0.00245)\end{array}$ & $\begin{array}{l}0.0173 * * * \\
(0.00262)\end{array}$ & $\begin{array}{l}0.0185 * * * \\
(0.00266)\end{array}$ \\
\hline Private institution & & $\begin{array}{l}-1.567 * * * \\
(0.148)\end{array}$ & $\begin{array}{l}-1.547 * * * \\
(0.149)\end{array}$ & $\begin{array}{l}-1.562 * * * \\
(0.149)\end{array}$ \\
\hline$\%$ Government funding & & $\begin{array}{l}-1.865 * * * \\
(0.329)\end{array}$ & $\begin{array}{l}-1.875^{* * *} \\
(0.330)\end{array}$ & $\begin{array}{l}-1.867 * * * \\
(0.329)\end{array}$ \\
\hline Research expense per faculty & & $\begin{array}{l}1.28 \mathrm{e}-06 * * * \\
(3.28 \mathrm{e}-07)\end{array}$ & $\begin{array}{l}1.29 \mathrm{e}-06^{* * * *} \\
(3.27 \mathrm{e}-07)\end{array}$ & $\begin{array}{l}1.28 \mathrm{e}-06^{* * * *} \\
(3.27 \mathrm{e}-07)\end{array}$ \\
\hline Tuition per student & & $\begin{array}{l}6.90 \mathrm{e}-05 * * * \\
(6.94 \mathrm{e}-06)\end{array}$ & $\begin{array}{l}6.88 \mathrm{e}-05^{* * * *} \\
(6.95 \mathrm{e}-06)\end{array}$ & $\begin{array}{l}6.89 \mathrm{e}-05^{* * * *} \\
(6.94 \mathrm{e}-06)\end{array}$ \\
\hline Large university & & $\begin{array}{l}0.651 * * * \\
(0.106)\end{array}$ & $\begin{array}{l}0.660 * * * \\
(0.106)\end{array}$ & $\begin{array}{l}0.653 * * * \\
(0.106)\end{array}$ \\
\hline Award $\mathrm{PhD}$ degrees & & $\begin{array}{l}0.546 * * * \\
(0.0898)\end{array}$ & $\begin{array}{l}0.555 * * * \\
(0.0900)\end{array}$ & $\begin{array}{l}0.547 * * * \\
(0.0899)\end{array}$ \\
\hline$\%$ Degrees awarded to blacks & & & $\begin{array}{l}-1.041^{*} \\
(0.598)\end{array}$ & \\
\hline$\%$ Blacks enrolled & & & & $\begin{array}{l}-0.216 \\
(0.536)\end{array}$ \\
\hline Constant & $\begin{array}{l}-2.741 * * * \\
(0.365)\end{array}$ & $\begin{array}{l}-2.140 * * * \\
(0.451)\end{array}$ & $\begin{array}{l}-2.074 * * * \\
(0.453)\end{array}$ & $\begin{array}{l}-2.123 * * * \\
(0.453)\end{array}$ \\
\hline State fixed effects & Yes & Yes & Yes & Yes \\
\hline Observations & 61,439 & 16,032 & 16,017 & 16,032 \\
\hline Pseudo R-squared & 0.0258 & 0.166 & 0.166 & 0.166 \\
\hline LR chi2 & 343.1 & 1393 & 1394 & 1393 \\
\hline Prob $>$ chi 2 & 0 & 0 & 0 & 0 \\
\hline
\end{tabular}

Standard errors in parentheses and clustered at the state level

$* * * p<0.01, * * p<0.05, * p<0.1$ 
HBCUs are less likely to apply to the Charles Koch Foundation for a grant. Nevertheless, the results using the best available data confirm significant disparities in the chances of receiving a grant from the foundation between HBCUs and non-HBCUs.

For the total dollar amount of grants, we limit the scope to institutions that have received at least one Charles Koch Foundation grant. Ordinary least squares (OLS) estimation is used for the total dollar amount of grants awarded:

$\ln \left(Y_{i t}\right)=\beta_{0}+\beta_{1} \mathrm{HBCU}_{i}+X_{i t} \beta+\varepsilon_{i t}$

where $Y_{i t}$ is the total dollar amount of grants awarded to institution $i$ in year $t$ from the Charles Koch Foundation, and $X_{i t}$ contains the same set of covariates as in Eq. (1). State fixed effects are not controlled for the total dollar amount of grants because being an HBCU could be highly correlated with state location for this analysis. There are only nine HBCUs that have ever received a grant from the Charles Koch Foundation. These HBCUs are concentrated in seven states: Alabama, Delaware, North Carolina, Georgia, South Carolina, Virginia, and Louisiana.

Table 3 shows the results of OLS regression on the total dollar amount of grants awarded to recipient institutions. For those institutions that have received a grant from the Charles Koch Foundation, the amount awarded to HBUCs is statistically significantly less than that to non-HBCUs. The difference remains after controlling for the first two sets of covariates. HBCUs received 19\% ([exp(-.207)-1]*100\%) less in the total dollar amount of grants awarded compared with non-HBCUs, as indicated in model (2) of Table 3. In terms of dollar amount, between 1998 and 2016, the Koch Foundation awarded HBCUs grants that, on average, were $\$ 544$ less than those awarded to non-HBCUs. This number may seem trivial, but it is the average number across 19 years for the 101 HBCUs and the 3637 non-HBCUs included in this study. However, when we control for the percentage of degrees awarded to blacks (model (3)) or the percentage of blacks enrolled (model (4)), the HBCU effect becomes statistically insignificant. ${ }^{2}$ This suggests that the HBCU effect is sensitive to how we account for the racial characteristics of institutions.

Similar to the results of the probability of receiving a grant, measures of high productivity are positively associated with the total dollar amount of grants awarded across models. Also, the dollar amount awarded to private institutions is less than that to public institutions. The reasons, once again, could be that private institutions usually rely less on public funds and are more flexible to increase tuition and fees. Contrary to our expectation, tuition per student is positively associated with

\footnotetext{
${ }^{2}$ The VIF (variance inflation factor, a measure of how much a variable contributes to the standard error in a regression) on the percentage of degrees awarded to blacks is 81.56 , and that on the percentage of blacks enrolled is 76.43 .
}

the dollar amount of grants awarded. The effect, nevertheless is trivial.

Considering that the number of grants awarded is quite different across recipient institutions, we are also interested in the average amount per grant an institution receives. For this analysis, we collapse the panel data into a cross-sectional dataset by averaging the institutional characteristic variables from 1998 to 2016. The average amount per grant is estimated with Eq. (3), with $Y_{i}$ being the average amount per grant received by institution $i . X_{i}$ denotes the same set of covariates in Eq. (1) that are collapsed to means across the years. Because this analysis also limits the scope to institutions that have received at least one grant from the Charles Koch Foundation, state fixed effects are not controlled for, for similar reasons mentioned previously.

$\ln \left(Y_{i}\right)=\beta_{0}+\beta_{1} \mathrm{HBCU}_{i}+X_{i} \beta+\varepsilon_{i}$

Table 4 outlines the results. Higher graduation rates, larger universities, and a higher percentage of expenses spent on research are associated with a higher amount per grant awarded. Although tuition per student is positively associated with the average amount per grant, the effect is minimal. On average, HBCUs received $52.3 \%$ less, or $\$ 1340$ less in dollar amount, per grant, compared with non-HBCUs. However, the magnitude of difference drops to less than $1 \%$ in model (2) and model (3) with covariates controlled.

In summary, the empirical evidence confirms that HBCUs are disadvantaged in the probability of receiving a grant from the Charles Koch Foundation and in the dollar amount received if they are awarded a grant. In addition, the empirical results support that the Charles Koch Foundation prefers institutions with existing high productivity. This finding suggests that there may be selection bias in any efforts to measure the impacts of grant funding on productivity.

High productivity institutions, which are found to be large, $\mathrm{PhD}$-granting institutions with higher graduation rates and more research expenses per faculty member, are more likely to receive grants from the Charles Koch Foundation and receive more total dollars and more dollars per grant among all grantee institutions.

As for the vulnerability of institutions, we find mixed results. For the probability of receiving a grant, strong evidence shows that institutions that receive a larger portion of their revenue from government funding are less likely to receive a grant. Private institutions, which usually rely less on public funds and have more room to subsidize financial shortfalls through increased tuition, are also less likely to receive a Charles Koch Foundation grant. However, tuition per student is positively associated with the probability of receiving a grant. For the dollar amount received, private institutions still received fewer dollars. Tuition per student is still positively and statistically significantly associated with the dollar 
Table 3 Ordinary least squares (OLS) regression on the natural log of total dollar amount of grants awarded

\begin{tabular}{|c|c|c|c|c|}
\hline & OLS (1) & OLS (2) & OLS (3) & OLS (4) \\
\hline $\mathrm{HBCU}$ & $\begin{array}{l}-0.658 * * * \\
(0)\end{array}$ & $\begin{array}{l}-0.207 * * \\
(0.00363)\end{array}$ & $\begin{array}{l}-0.347 \\
(0.196)\end{array}$ & $\begin{array}{l}-0.0751 \\
(0.112)\end{array}$ \\
\hline Graduation rate & & $\begin{array}{l}0.00910^{* *} \\
(0.000275)\end{array}$ & $\begin{array}{l}0.00939 * * * \\
(0.000129)\end{array}$ & $\begin{array}{l}0.00875 * * * \\
(1.85 \mathrm{e}-05)\end{array}$ \\
\hline Private institution & & $\begin{array}{c}-0.356^{*} \\
(0.0460)\end{array}$ & $\begin{array}{c}-0.361^{*} \\
(0.0511)\end{array}$ & $\begin{array}{l}-0.353 * \\
(0.0491)\end{array}$ \\
\hline$\%$ Government funding & & $\begin{array}{l}0.0598 \\
(0.0534)\end{array}$ & $\begin{array}{l}0.0614 \\
(0.0478)\end{array}$ & $\begin{array}{l}0.0568 \\
(0.0531)\end{array}$ \\
\hline Research expense per faculty & & $\begin{array}{l}5.48 \mathrm{e}-07 * \\
(4.42 \mathrm{e}-08)\end{array}$ & $\begin{array}{l}5.46 \mathrm{e}-07 * * \\
(3.69 \mathrm{e}-08)\end{array}$ & $\begin{array}{l}5.50 \mathrm{e}-07^{*} \\
(4.53 \mathrm{e}-08)\end{array}$ \\
\hline Tuition per student & & $\begin{array}{l}1.88 \mathrm{e}-05^{* *} \\
(7.03 \mathrm{e}-07)\end{array}$ & $\begin{array}{l}1.88 \mathrm{e}-05 * * \\
(7.63 \mathrm{e}-07)\end{array}$ & $\begin{array}{l}1.88 \mathrm{e}-05^{* *} \\
(6.92 \mathrm{e}-07)\end{array}$ \\
\hline Large university & & $\begin{array}{l}0.454 * * \\
(0.00799)\end{array}$ & $\begin{array}{l}0.452 * * \\
(0.0101)\end{array}$ & $\begin{array}{l}0.458 * * \\
(0.0115)\end{array}$ \\
\hline Award $\mathrm{PhD}$ degrees & & $\begin{array}{l}0.323 * \\
(0.0484)\end{array}$ & $\begin{array}{l}0.322 * \\
(0.0500)\end{array}$ & $\begin{array}{l}0.324 * \\
(0.0492)\end{array}$ \\
\hline$\%$ Degrees awarded to blacks & & & $\begin{array}{l}0.212 \\
(0.292)\end{array}$ & \\
\hline$\%$ Blacks enrolled & & & & $\begin{array}{l}-0.195 \\
(0.161)\end{array}$ \\
\hline Constant & $\begin{array}{l}9.710 * * * \\
(0)\end{array}$ & $\begin{array}{l}8.483 * * * \\
(0.0797)\end{array}$ & $\begin{array}{l}8.454 * * * \\
(0.0376)\end{array}$ & $\begin{array}{l}8.518 * * * \\
(0.0521)\end{array}$ \\
\hline Observations & 1392 & 1168 & 1168 & 1168 \\
\hline R-squared & 0.003 & 0.121 & 0.121 & 0.121 \\
\hline
\end{tabular}

Robust standard errors in parentheses $* * * p<0.01, * * p<0.05, * p<0.1$

amount received. However, the share of government funding in total revenue is no longer statistically significant. The reasons for such mixed results could be due to selection bias, as mentioned previously. Institutions with more government funding support may be less likely to apply to the Charles Koch Foundation. Once an institution applied for and received a grant, government funding support no longer matters for the dollar amount they received from the foundation. Similarly, the observed disadvantages of private institutions in the probability of receiving a grant and the dollar amount of grant received could be due to the fact that private institutions are less likely to turn to the Charles Koch Foundation as their first option. More information, such as all applicants to the Charles Koch Foundation and their grant results, is needed to better test the proposition that the foundation is targeting vulnerable and controllable institutions.

\section{Charles Koch Foundation Grants and Economics Productivity at HBCUs}

To address the question of the impacts of Koch funding on research productivity, we focus only on the $101 \mathrm{HBCUs}$ that report data to IPEDS. The motivation behind the second question is to tease out the effects of Charles Koch Foundation grants on economics productivity at HBCUs and thus to address people's suspicions and concerns about the foundation's involvement in HBCUs.

Each HBCU's engagement with the Charles Koch Foundation is measured in three ways: (1) whether it ever received a grant from the foundation, (2) the total dollar amount of grants received, and (3) the average amount received per grant. These three measures represent the treatments. The outcome measure, research productivity, is measured in three different ways: (1) the number of economics publications per faculty member; (2) the number of citations in published economics papers per faculty member; and (3) the probability of publishing in one of the top 30 economics journals. Our goal is to estimate the (treatment) effects of Koch funding on research productivity.

Data on economics publications and citations of all HBCUs were retrieved from Scopus by limiting affiliation to each of the $101 \mathrm{HBCUs}$; fields to economics, econometrics, and finance; years to 1988-2016; and document type to articles. Because the Charles Koch Foundation began funding HBCUs in 2010, all variables for this analysis are aggregated from 1988 to 2009 to account for the pre-funding period and from 2010 to 2016 to account for the post-funding period. 


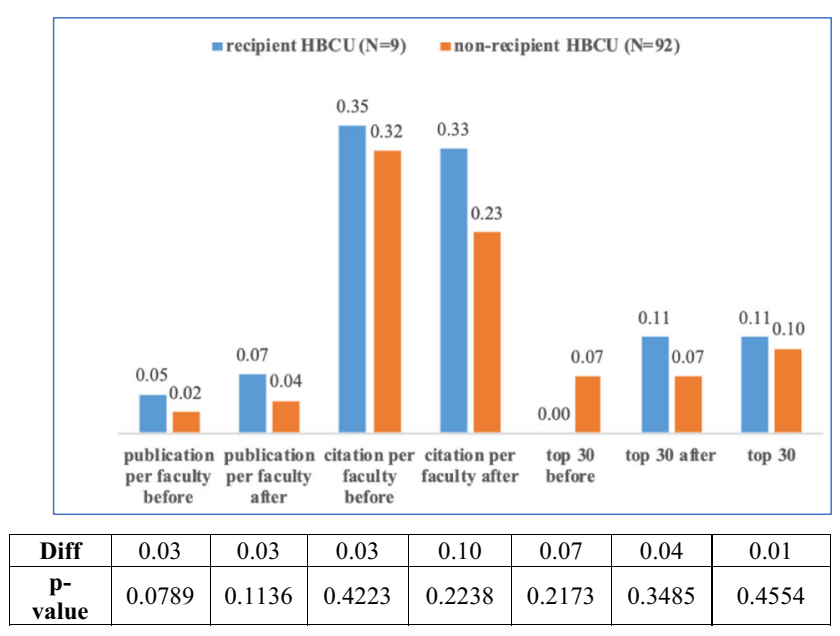

Fig. 5 Difference in productivity between recipient and non-recipient HBCUs

Figure 5 shows the differences between recipient HBCUs and non-recipient HBCUs in different measures of productivity before and after 2010. Recipient HBCUs have higher productivity than non-recipients do in all measures, both before and after 2010, except for "top 30 before". Prior to the Charles Koch Foundation's funding of HBCUs, the recipient HBCUs never published in one of the top 30 journals. However, after receiving funding from the Charles Koch Foundation (beginning in 2010), their probability of publishing in the top 30 journals increased and exceeded that of non-recipient HBCUs.

We first apply the OLS estimator on the measures of productivity and report the results in the corresponding tables. The OLS results, however, are likely to be biased due to non-random sample selection. Therefore, we adopt a twostep model estimator (Dow and Norton 2003; Frondel and Vance 2012) to control for the potential selection bias. ${ }^{3}$ Specifically, in the first part, as indicated in Eq. (4), ${ }^{4}$ we define a dichotomous variable $R$, where $R=1$ when we observe positive values of productivity in period $t\left(P_{i t}>0\right)$, otherwise $R=$ 0 .We use the logit model to estimate the likelihood of observing a positive value $\left(P_{i t}{ }^{*}>0\right)$ when controlling a vector of associated factors $\left(X_{i t}\right)$. With the estimated $\gamma_{i t}$, for the second part, we adopt the generalized linear model (GLM) to estimate the parameters $(\beta s)$ that correlate with the expected value $\left(E\left[P_{i t} \mid R=1, X_{i t}\right]\right)$ conditional on $P_{i t}>0$, as shown in Eq. (5).

$\left\{\begin{array}{c}R=1, \text { if } P_{i t}^{*}=\sum \gamma_{i} X_{i t}+\varepsilon_{i t}>0 \\ 0, \text { if } P_{i t}{ }^{*} \leqq 0\end{array}\right.$

\footnotetext{
${ }^{3}$ Unlike the Heckman correction, the two-step model adopted in this paper does not require the exclusion restriction assumption. The variables can be the same for the first-part and second-part regressions.

${ }^{4} \varepsilon_{i t}$ is assumed to have a standard normal distribution.
}

$$
\begin{gathered}
E\left[P_{i t} \mid R=1, X_{i t}\right]=E\left[P_{i t}>0, X_{i t}\right] \\
=\beta_{0}+\beta_{1} \operatorname{Koch}_{i t}+\beta_{2} P_{i(t-1)}+X_{i t} \beta+\alpha_{i}+\varepsilon_{i t}
\end{gathered}
$$

In Eq. (5), $\mathrm{Koch}_{i t}$ denotes a vector including the three measures of funding from the Charles Koch Foundation for institution $i$ at time $t . P_{i(t-1)}$ denotes productivity before 2010 for institution $i ; X_{i t}$ denotes a vector including all covariates in previous models except for HBCUs for institution $i$ at time $t$, and $\alpha_{i}$ refers to the state fixed effects to eliminate biases that vary across states. Due to particular interest in economics productivity in this study, whether an HBUC offers degrees in economics is also controlled.

Table 5 reports the covariate definitions used in productivity estimation.

\section{The Effects of Koch Funding on Publications}

Table 6 displays both the OLS and the final estimates from the two-step model on the first measure of productivity: number of publications per faculty between 2010 and $2016 .{ }^{6}$ The first column reports the effect of receiving Koch funding on the number of publications from the OLS model. The second column reports the estimates of the effect of Koch funding on the number of publications using the GLM estimates in the two-step model. The third column reports the GLM estimates of the effects of the ln (amount Koch funding) on publications. The fourth column reports the GLM estimates of the effects of the $\ln$ (average Koch funding per grant). We cannot apply the OLS estimator on the effect of the $\ln$ (amount Koch funding) or the effect of the ln (average Koch funding per grant) given that there are only 9 HBCUs that ever received grants from the Koch Foundation. Therefore, we face many zero values of $\ln$ (amount Koch funding) and ln (average Koch funding per grant). Columns 2 to 4 report the estimated treatment effects from a generalized linear model conditioning on the probability of positive faculty publications. ${ }^{7}$ From the OLS model, we find that receiving a Koch grant increases the number of economics publications per faculty by 0.0085 . This minuscule effect is not statistically significant. Once we control for some potential selection in awarding a Koch grant in the two-step model, the effect dramatically decreases to 0.0008 economics publications per faculty. It again is not statistically significant at any statistical significance level. Furthermore, each extra dollar of Koch grant funding fails to

\footnotetext{
The two-step models assume that $E\left(\varepsilon_{2} \mid P_{i t}>0, X_{i t}\right)=0$, therefore, $E\left[P_{i t} \mid R=1, X_{i t}\right]=\beta X_{i t}^{\prime}$.

${ }^{6}$ Appendix Table 14 reports the first step estimates, which are the logit regressions on the likelihood of observing a positive per-faculty number of publications.

${ }^{7}$ Different from the Heckman selection model, the two-step model allows the same covariates for both the first part and second part.
} 
Table 4 Ordinary least squares (OLS) regression on the natural log of average amount per grant awarded

\begin{tabular}{|c|c|c|c|c|}
\hline & OLS (1) & OLS (2) & OLS (3) & OLS (4) \\
\hline $\mathrm{HBCU}$ & $\begin{array}{l}-0.740 * * * \\
(0.000)\end{array}$ & $\begin{array}{l}-0.0659^{*} \\
(0.0127)\end{array}$ & $\begin{array}{l}-0.0811^{* *} \\
(0.00317)\end{array}$ & $\begin{array}{l}0.0232 \\
(0.188)\end{array}$ \\
\hline Graduation rate & & $\begin{array}{l}0.00969 * * \\
(0.000519)\end{array}$ & $\begin{array}{l}0.00972 * * \\
(0.000499)\end{array}$ & $\begin{array}{l}0.00945 * * * \\
(8.46 \mathrm{e}-06)\end{array}$ \\
\hline Private institution & & $\begin{array}{l}-0.636 \\
(0.111)\end{array}$ & $\begin{array}{l}-0.637 \\
(0.111)\end{array}$ & $\begin{array}{l}-0.634 \\
(0.115)\end{array}$ \\
\hline$\%$ Government funding & & $\begin{array}{l}-0.862 \\
(0.147)\end{array}$ & $\begin{array}{l}-0.863 \\
(0.147)\end{array}$ & $\begin{array}{l}-0.861 \\
(0.152)\end{array}$ \\
\hline Research expense per faculty & & $\begin{array}{l}2.16 \mathrm{e}-06^{* *} \\
(6.30 \mathrm{e}-08)\end{array}$ & $\begin{array}{l}2.16 \mathrm{e}-06^{* *} \\
(6.23 \mathrm{e}-08)\end{array}$ & $\begin{array}{l}2.16 \mathrm{e}-06^{* *} \\
(5.95 \mathrm{e}-08)\end{array}$ \\
\hline Tuition per student & & $\begin{array}{l}1.16 \mathrm{e}-05^{* *} \\
(5.74 \mathrm{e}-07)\end{array}$ & $\begin{array}{l}1.16 \mathrm{e}-05^{* *} \\
(5.80 \mathrm{e}-07)\end{array}$ & $\begin{array}{l}1.17 \mathrm{e}-05^{* *} \\
(3.25 \mathrm{e}-07)\end{array}$ \\
\hline Large university & & $\begin{array}{l}0.379 * * \\
(0.0253)\end{array}$ & $\begin{array}{l}0.378 * * \\
(0.0248)\end{array}$ & $\begin{array}{l}0.382 * * \\
(0.0193)\end{array}$ \\
\hline Award $\mathrm{PhD}$ degrees & & $\begin{array}{l}0.383 \\
(0.110)\end{array}$ & $\begin{array}{l}0.383 \\
(0.109)\end{array}$ & $\begin{array}{l}0.381 \\
(0.107)\end{array}$ \\
\hline$\%$ Degrees awarded to blacks & & & $\begin{array}{l}0.0211 \\
(0.0131)\end{array}$ & \\
\hline$\%$ Blacks enrolled & & & & $\begin{array}{l}-0.122 \\
(0.276)\end{array}$ \\
\hline Constant & $\begin{array}{l}9.629 * * * \\
(0)\end{array}$ & $\begin{array}{l}8.867 * * \\
(0.178)\end{array}$ & $\begin{array}{l}8.865 * * \\
(0.176)\end{array}$ & $\begin{array}{l}8.887 * * * \\
(0.132)\end{array}$ \\
\hline Observations & 411 & 391 & 391 & 391 \\
\hline R-squared & 0.007 & 0.202 & 0.202 & 0.202 \\
\hline
\end{tabular}

Robust standard errors in parentheses

$* * * p<0.01, * * p<0.05, * p<0.1$ increase the number of economic publications at any statistical significance level. The non-statistically significant results from both the OLS and GLM results mean that there are no statistically significant impacts from Charles Koch Foundation grants on the number of economics publications at HBCUs, the first of our three measures of productivity.

Given that the productivity data are count data, we also used a Poisson regression model to re-estimate some of the results as a robustness check. Table 7 shows the Poisson regression results, which are similar to the OLS results. For example, column 1 shows that publications of HBCUs that has received a Koch grant are 1.3 times $(\exp (0.2728))$ higher, but the effect is not statistically significant. The conclusion that Koch Foundation giving has a positive, but statistically insignificant, effect on HBCUs' economics publications remains when using the Poisson specification.

\section{The Effects of Koch Funding on Citations}

We now turn to the treatment effects of Koch funding on citations. Table 8 presents the results for the second measure of productivity by the number of citations per faculty, using the same methods reported for the estimates of the effects of Koch funding on the number of publications - our first productivity measure. Again, we specify four models to estimate the effect of receiving a Koch grant on productivity. ${ }^{8}$ Getting a grant from the foundation and the average amount received per grant has significant positive impacts on the number of citations per faculty member at a $90 \%$ confidence level from both the OLS estimator and the two-step model. The OLS results indicate that receiving a Koch grant increases by 0.2 citations per faculty at the $90 \%$ significance level. The two-step model shows similar results: Conditional on having any citations, HBCUs that have ever received a grant from the Charles Koch Foundation produce 0.2 extra citations per faculty member compared with those HBCUs that did not receive a grant from the foundation. Also, conditional on having any citations, an increase in the average amount per grant is associated with an increase

\footnotetext{
${ }^{8}$ Appendix Table 15 reports the first step estimates, which is the logit regression on the likelihood of observing a positive per faculty number of citations.
} 
Table 5 Covariate definitions inproductivity estimation
Table 6 OLS and 2-step GLM estimates of the effects of Koch funding on the number of economics publications per faculty member, year: 2010-2016

\begin{tabular}{|c|c|}
\hline Variable & Description \\
\hline Public HBCU & Public Historically Black College or University \\
\hline Economics degrees & Offer a bachelor's degree in the economics major \\
\hline Publication per faculty_2009 & Economics publications per faculty member between 1988 and 2009 \\
\hline Black faculty share_2016 & $\begin{array}{l}\text { The average share of black faculty membersamong all faculty members from } \\
2010 \text { to } 2016\end{array}$ \\
\hline High share of black faculty & The average share of black faculty members is more than $50 \%$ \\
\hline Small HBCU_2016 & Average student enrollment under 5000 between 2010 and 2016 \\
\hline Medium HBCU_2016 & Average student enrollment between 5000 and 15,000 between 2010 and 2016 \\
\hline Graduation rate_2009 & Average graduation rate between 1988 and 2009 \\
\hline Graduation rate_2016 & Average graduation rate between 2010 and 2016 \\
\hline Received Koch grant & Received grants from Charles Koch between 2010 and 2016 \\
\hline $\begin{array}{l}\text { Ln (total amount Koch } \\
\text { grant) }\end{array}$ & $\begin{array}{l}\text { Natural log of the annual total dollar amount received from Charles Koch grants } \\
\text { between } 2010 \text { and } 2016\end{array}$ \\
\hline $\begin{array}{l}\text { Ln (average amount per } \\
\text { Koch grant) }\end{array}$ & $\begin{array}{l}\text { Natural log of the annual average dollar amount per grant from Charles Koch } \\
\text { between } 2010 \text { and } 2016\end{array}$ \\
\hline Top 30_before & Has publications in one of the top 30 economics journals between 1998 and 2009 \\
\hline
\end{tabular}

\begin{tabular}{|c|c|c|c|c|}
\hline & OLS (1) & 2-Step GLM (2) & 2-Step GLM (3) & 2-Step GLM (4) \\
\hline \multirow[t]{2}{*}{ Public HBCU } & -0.0009 & -0.0141 & -0.0140 & -0.0141 \\
\hline & $(0.0166)$ & $(0.0186)$ & $(0.0185)$ & $(0.0185)$ \\
\hline \multirow[t]{2}{*}{ Economics degrees } & 0.0133 & 0.0218 & 0.0216 & 0.0219 \\
\hline & $(0.0232)$ & $(0.0257)$ & $(0.0255)$ & $(0.0256)$ \\
\hline \multirow[t]{2}{*}{ Publication per faculty_2009 } & $0.7450 * * *$ & $0.5213 * * *$ & $0.5225 * * *$ & $0.5207 * * *$ \\
\hline & $(0.1257)$ & $(0.1435)$ & $(0.1440)$ & $(0.1437)$ \\
\hline \multirow[t]{2}{*}{ Black faculty share_2016 } & $-0.0901 * *$ & -0.0838 & -0.0839 & -0.0837 \\
\hline & $(0.0346)$ & $(0.0564)$ & $(0.0570)$ & $(0.0567)$ \\
\hline \multirow[t]{2}{*}{ Small HBCU_2016 } & -0.0013 & -0.0138 & -0.0136 & -0.0138 \\
\hline & $(0.0159)$ & $(0.0139)$ & $(0.0140)$ & $(0.0139)$ \\
\hline \multirow[t]{2}{*}{ Graduation rate_2016 } & -0.0359 & -0.0681 & -0.0670 & -0.0686 \\
\hline & $(0.0416)$ & $(0.0703)$ & $(0.0694)$ & $(0.0698)$ \\
\hline \multirow[t]{2}{*}{ Received Koch grant } & 0.0085 & 0.0008 & & \\
\hline & $(0.0238)$ & $(0.0243)$ & & \\
\hline \multirow[t]{2}{*}{ Ln (total amount Koch grant) } & & & -0.0000 & \\
\hline & & & $(0.0025)$ & \\
\hline \multirow[t]{2}{*}{ Ln (average amount per Koch grant) } & & & & 0.0001 \\
\hline & & & & $(0.0028)$ \\
\hline \multirow[t]{2}{*}{ Constant } & $0.0836^{* *}$ & $0.1364 * *$ & $0.1360 * *$ & $0.1365^{* *}$ \\
\hline & $(0.0324)$ & $(0.0535)$ & $(0.0536)$ & $(0.0535)$ \\
\hline State fixed effects & Yes & Yes & Yes & Yes \\
\hline Observations & 101 & 101 & 101 & 101 \\
\hline Second step likelihood & & 85.36 & 85.36 & 85.36 \\
\hline Chi squared & & 28.83 & 28.97 & 28.66 \\
\hline F-score & 31.01 & & & \\
\hline
\end{tabular}

Robust standard errors in parentheses and clustered at the state level

$* * * p<0.01, * * p<0.05, * p<0.1$ 
Table 7 Poisson estimates of the effects of Koch funding on number of economics publications

\begin{tabular}{llll}
\hline & Poisson (1) & Poisson (2) & Poisson (3) \\
\hline Public HBCU & 0.1407 & 0.1407 & 0.1401 \\
Small HBCU_2016 & $(0.6154)$ & $(0.6154)$ & $(0.6141)$ \\
& $-3.6454^{* * *}$ & $-3.6460^{* * *}$ & $-3.6600^{* * *}$ \\
Medium HBCU_2016 & $(0.7346)$ & $(0.7344)$ & $(0.7390)$ \\
& $-1.5944^{* * *}$ & $-1.5950^{* * *}$ & $-1.6062^{* * *}$ \\
High share of black faculty & $(0.3423)$ & $(0.3423)$ & $(0.3468)$ \\
& -0.2599 & -0.2620 & -0.2976 \\
Received Koch grant & $(0.3052)$ & $(0.3046)$ & $(0.3187)$ \\
Ln (total amount Koch grant) & 0.2728 & & \\
Ln (average amount per Koch grant) & $(0.4608)$ & & \\
Constant & & 0.0271 & -0.0000 \\
Year fixed effects & & $(0.0503)$ & $(0.0000)$ \\
State fixed effects & & & -0.8287 \\
Observations & $-0.8720^{*}$ & $-0.8699^{*}$ & $(0.5486)$ \\
\hline
\end{tabular}

Robust standard errors in parentheses

$* * * p<0.01, * * p<0.05, * p<0.1$ in the number of citations per faculty member, by a tiny 0.0002 citations for every $1 \%$ increase in the average amount per grant. Thus, using the second measure of productivity, we find small but barely significant impacts from Koch funding.

Given that the citations are count data, we re-estimated the model of the effects of Koch funding using a Poisson regression method. Table 9 reports the estimation results. The impacts of Koch funding are seen now to be statistically insignificant. In short, the initial finding of a positive and barely significant impact of Koch funding on citations in the OLS and GLM estimates is not robust across alternative model estimation techniques.

\section{The Effects of Koch Funding on Publications in Top Journals}

For the third measure of economics productivity - publications in top journals - we use a logit model to estimate the probability of publishing in a top 30 economics journal from 2010 to 2016 :

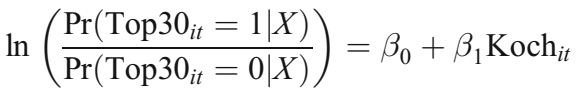

$$
\begin{aligned}
& +\beta_{2} \operatorname{Top} 30_{i(t-1)} \sum_{i} \beta_{i} X_{i}+\epsilon_{i t}
\end{aligned}
$$

where $\operatorname{Pr}\left(\operatorname{Top}_{30} 0_{i t}\right)$ denotes the probability of publishing in the top 30 journals for HBCU $i$ at time $t$; $\operatorname{Koch}_{i}$ is a vector of the three measures of funding from the Charles Koch Foundation; Top $30_{i(t-1)}$ denotes whether HBCU $i$ published in the top 30 journals before 2010, and $X_{i}$ is a vector of controlled variables.

Table 10 outlines the results for the third measure of productivity by the probability of publishing in one of the top 30 economics journals. The odds ratio of being published in a top 30 journals as a result of receiving a Charles Koch Foundation grant is 2.5 (exp (0.9089)). This effect, however, is not significant at any statistical significance level. Moreover, the non-significant effect is stable across the three measures of grant results. That is to say, there is no significant effect of receiving a Charles Koch Foundation grant on the probability of publishing in one of the top 30 economics journals. Table 10 also reports that public HBCUs and small HBCUs are less likely to publish in the top journals.

In summary, across multiple model specifications and estimation techniques, we find no impacts from Koch fundingwhether measured by a dichotomous measure of recipiency of funding or measured by the amount of funding - on two of the three measures of productivity. Whether we measure productivity by numbers of publications or by publication in top journals, there is no statistically significant impact of Koch funding on productivity. 
Table 8 OLS and two-step GLM estimates of the effects of Koch funding on the economics publication citations per faculty member, years 2010-2016

\begin{tabular}{|c|c|c|c|c|}
\hline & OLS (1) & 2-Step GLM (2) & 2-Step GLM (3) & 2-Step GLM (4) \\
\hline \multirow[t]{2}{*}{ Public HBCU } & -0.0645 & -0.5131 & -0.5161 & -0.5157 \\
\hline & $(0.1539)$ & $(0.4521)$ & $(0.4549)$ & $(0.4539)$ \\
\hline \multirow[t]{2}{*}{ Economics degrees } & 0.0923 & 0.2841 & 0.2798 & 0.2792 \\
\hline & $(0.1387)$ & $(0.2284)$ & $(0.2289)$ & $(0.2281)$ \\
\hline \multirow[t]{2}{*}{ Publication per faculty_2009 } & -0.0645 & $0.3445^{*}$ & $0.3446^{*}$ & $0.3444 *$ \\
\hline & $(0.1539)$ & $(0.1890)$ & $(0.1892)$ & $(0.1890)$ \\
\hline \multirow[t]{2}{*}{ Black faculty share_2016 } & -0.1921 & -0.1279 & -0.1201 & -0.1225 \\
\hline & $(0.2237)$ & $(0.5407)$ & $(0.5471)$ & $(0.5446)$ \\
\hline \multirow[t]{2}{*}{ Small HBCU_2016 } & 0.1252 & -0.0916 & -0.0884 & -0.0898 \\
\hline & $(0.2297)$ & $(0.1650)$ & $(0.1645)$ & $(0.1645)$ \\
\hline \multirow[t]{2}{*}{ Graduation rate_2016 } & -0.9049 & -2.9690 & -2.9561 & -2.9508 \\
\hline & $(0.9327)$ & $(2.1183)$ & $(2.1214)$ & $(2.1139)$ \\
\hline \multirow[t]{2}{*}{ Received Koch grant } & $0.2156^{*}$ & $0.2041^{*}$ & & \\
\hline & $(0.1052)$ & $(0.1157)$ & & \\
\hline \multirow[t]{2}{*}{ Ln (total amount Koch grant) } & & & 0.0204 & \\
\hline & & & $(0.0129)$ & \\
\hline \multirow[t]{2}{*}{ Ln (average amount per Koch grant) } & & & & $0.0219 *$ \\
\hline & & & & $(0.0132)$ \\
\hline \multirow[t]{2}{*}{ Constant } & 0.3900 & 1.6750 & 1.6682 & 1.6686 \\
\hline & $(0.2505)$ & $(1.0204)$ & (1.0179) & $(1.0183)$ \\
\hline State fixed effects & Yes & Yes & Yes & Yes \\
\hline Observations & 101 & 101 & 101 & 101 \\
\hline Second step likelihood & & -58.05 & -58.06 & -58.07 \\
\hline Chi squared & & 9.833 & 9.461 & 9.821 \\
\hline F-Square & 33.34 & & & \\
\hline
\end{tabular}

Robust standard in parentheses and clustered at the state level $* * * p<0.01, * * p<0.05, * p<0.1$
When citations measure productivity, we do observe limited evidence showing barely statistically significant effects of Charles Koch Foundation grants on economics productivity among HBCUs that have reported data to IPEDS. Compared with non-recipient HBCUs, those HBCUs that have ever received a grant from the Charles Koch Foundation have slightly more citations per faculty member. Dollars per grant to HBCUs are also positively associated with the number of citations per faculty member in HBCUs.

\section{Event Study Analysis and Difference-in-Differences Estimation}

Another way to consider whether Koch funding enhanced $\mathrm{HBCU}$ economics productivity is to model the effects of funding through an event study analysis, or a DID estimation. We apply event history analysis (see, for example, Kothari and Warner 2007; MacKinlay 1997) to examine whether there are statistically significant differences in economics publications and economics publications per faculty member between Koch funded and non-Koch funded HBCUs in pre- and post-2010. We define the event window as 2010 and construct a pre- and post-event window of \pm 5 years. Specifically, for HBCUs that received Koch grants, the pre-event years are coded as 2005 and earlier years (i.e., event year -5), 2006 (event year -4), 2007 (event year -3), 2008 (event year -2), and 2009 (event year -1 ), while the post-event years are 2011 (event year +1 ), 2012 (event year +2 ), 2013 (event year +3 ), 2014 (event year +4 ), and 2015 or 2016 (event year +5 ). We assign non-Koch funded HBCUs an event year of -1 (i.e., assign the year of 2009), and event year -1 is used as the comparison group. Thus, the event year dummy variables capture the economics publications and economics publications per faculty member deviation from the "overall" level. Since the sample is predominantly by non-Koch funded HBCUs, the "overall" level is primarily based on all year's sample mean of non-Koch funded HBCUs. 
Table 9 Poisson estimates of the effects of Koch funding on the number of citations

\begin{tabular}{llll}
\hline & Poisson (1) & Poisson (2) & Poisson (3) \\
\hline Public HBCU & 0.6598 & 0.6597 & 0.6571 \\
Small HBCU_2016 & $(0.6466)$ & $(0.6466)$ & $(0.6449)$ \\
& $-2.2885^{* * *}$ & $-2.2890^{* * *}$ & $-2.3184^{* * *}$ \\
Medium HBCU_2016 & $(0.8401)$ & $(0.8401)$ & $(0.8460)$ \\
& $-1.5598^{* * *}$ & $-1.5603 * * *$ & $-1.5780^{* * * *}$ \\
High share of black faculty & $(0.3516)$ & $(0.3513)$ & $(0.3575)$ \\
& 0.1851 & 0.1828 & 0.0935 \\
Received Koch grant & $(0.3949)$ & $(0.3944)$ & $(0.3970)$ \\
Ln (total amount Koch grant) & 0.6979 & & \\
Ln (average amount per Koch grant) & $(0.7518)$ & & \\
Constant & & 0.0744 & \\
Year fixed effects & & $(0.0816)$ & $(0.0000)$ \\
State fixed effects & & & 0.6967 \\
Observations & & & $(0.7937)$ \\
\hline
\end{tabular}

Robust standard errors in parentheses

$* * * p<0.01, * * p<0.05, * p<0.1$
Formally, the event study specification is

$P_{i t}=\beta_{0}+\sum_{l=-5}^{-2} \beta_{l} D_{l}+\sum_{l=0}^{5} \beta_{l} D_{l}+X_{i t} \gamma+\varepsilon_{i t}$
In Eq. (7), $P_{i t}$ denotes the total publications or publications per faculty member; $\left\{D_{-5}, D_{-4}, \ldots, D_{-2}, D_{0}, \ldots, D_{5}\right\}$ denotes a series of dummy variables for each event year, with the event
Table 10 Maximum likelihood estimates of coefficients in logistic models of the probability of publishing in top 30 economics journals

\begin{tabular}{llll}
\hline & $(1)$ & $(2)$ & $(3)$ \\
\hline Top 30_before & 1.7015 & 1.7377 & 1.7413 \\
& $(1.4053)$ & $(1.4118)$ & $(1.4160)$ \\
Black faculty share_2016 & -1.8178 & -1.6905 & -1.7294 \\
Public HBCU & $(2.6445)$ & $(2.6061)$ & $(2.6155)$ \\
& $-16.9912^{* * * *}$ & $-16.9975 * * *$ & $-15.9962^{* * *}$ \\
Small HBCU_2016 & $(0.9637)$ & $(0.2372)$ & $(0.9574)$ \\
& $-18.2775^{* * *}$ & -18.2693 & $-17.2470^{* * *}$ \\
Economics degrees & $(0.8626)$ & $()$. & $0.9964)$ \\
& 0.7283 & 0.7438 & 0.7323 \\
Graduation rate_2016 & $(2.1829)$ & $(2.1813)$ & $(2.1699)$ \\
Received Koch grant & 0.7010 & 0.6230 & $(2.58363$ \\
& $(2.6001)$ & $(2.5559)$ & \\
Ln (total amount Koch grant) & 0.9089 & & \\
& $(1.2247)$ & & 0.1015 \\
Ln (average amount per Koch grant) & & $(0.1351)$ & $(0.1269)$ \\
& & & $14.7424 * * *$ \\
Constant & & $15.7293 * * *$ & $(2.3531)$ \\
Observations & $15.8007 * * *$ & $(2.0525)$ & 101 \\
Chi squared & $(2.3437)$ & 101 & 782.12 \\
Pseudo $R^{2}$ & 101 & & 0.365 \\
\hline
\end{tabular}

Robust standard errors in parentheses

$* * * p<0.01, * * p<0.05, * p<0.1$ 
year -1 as the reference; $X_{i t}$ is a set of control variables; $\epsilon_{i t}$ is the error term; and $(\beta, \gamma)$ denotes the vector of parameters. We include whether the institution offers a bachelor's degree in economics, whether it is a public HBCU, the annual average graduation rate, average student enrollment is under 5000, and whether the average share of black faculty members is greater than $50 \%$ as control variables. All estimates account for institutional and state fixed effects.

Figure 6 and Fig. 7 plot the point estimations and confidence intervals of the event dummy variables from specifications with and without control variables for economics publications and economics publications per faculty member. As Figs. 6 and 7 reveal, all of the confidence intervals include 0 , and thus indicate statistically insignificant pre- and post-event deviations from the overall sample mean. We can draw two conclusions from the statistically insignificant year dummy variables. (1) There is no statistically significant pre-event difference between Koch funded HBCUs and the non-Koch funded HBCUs. (2) In short, we find no statistically significant effect of Koch funds on economics publications and economics publications per faculty member.

As the event study indicates, there is no statistically significant difference between the productivity of Koch funded HBCUs and non-Koch funded HBCUs for the years before 2010. Thus, the non-Koch funded HBCUs can serve as a legitimate control group for the Koch funded HBCUs, which is the treatment group. Table 11 produces alternative difference-in-differences (DID) estimates of the effects of Koch funding on economics publications and economics publications per faculty member. The coefficient of the interaction term Received Koch grant* Post funding period is the difference between the publication productivity of Koch funded and non-funded institutions before and after Koch funding began to HBCUs in 2010. We control the same set of covariates as the event history analysis. Models 2, 3, 5, and 6 also account

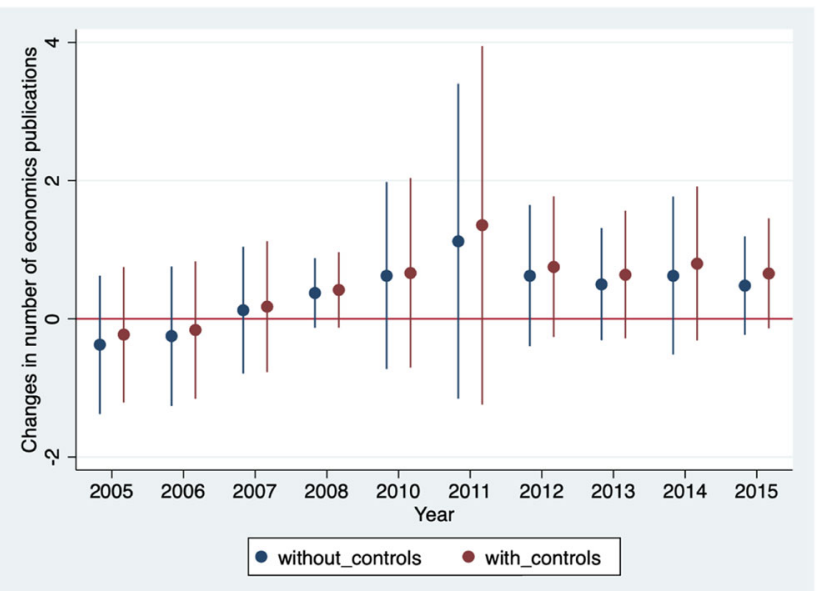

Fig. 6 Event history analysis: number of publications. Note:Each year's coefficient represents the changes in number of economics publications between Koch funded HBCUs and non-Koch funded HBCUs

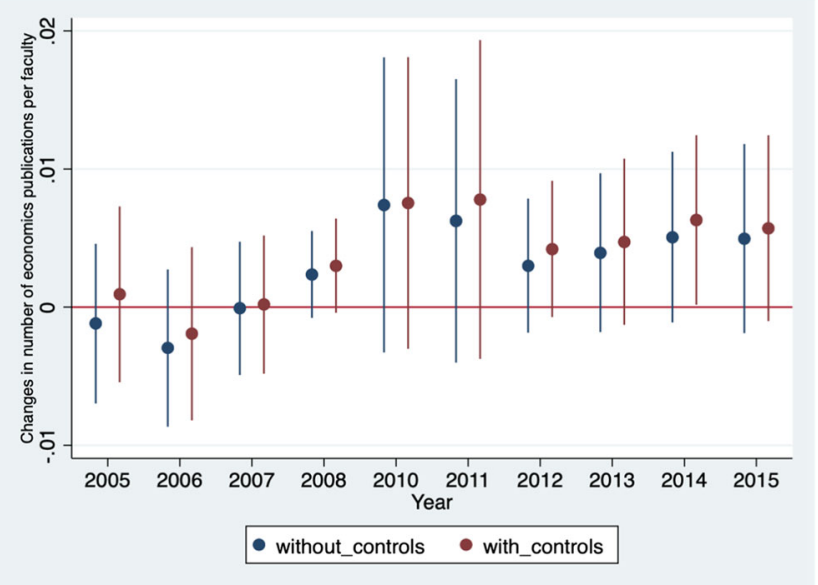

Fig. 7 Event history analysis: publications per faculty member. Note:Each year's coefficient represents the changes in number of 21 economics publications per faculty member between Koch funded HBCUs and non-Koch funded HBCUs

for year fixed effects. Across all six specifications of the model, the effects of Koch funding are positive but statistically insignificant. The DID estimates mirror all of the previous estimations showing no statistically meaningful impact of Koch funding on HBCU research productivity.

\section{Conclusions and Discussion}

This paper joins the ongoing heated discussions on the influence of money from the conservative Charles Koch Foundation on higher education. Using data compiled from tax forms of the Charles Koch Foundation, IPEDS, and Scopus, this paper answers two questions: (1) What are the factors that explain the grant results from the Charles Koch Foundation? And (2) Does funding from the Charles Koch Foundation improve economics productivity at HBCUs?

The results show that institutional characteristics are associated with grant results in terms of the probability of receiving a grant and the dollar amount of grants awarded by the Charles Koch Foundation. Specifically, public institutions are associated with a higher likelihood of receiving a grant as well as a greater total dollar amount of the grants awarded. The reasons could be that public institutions rely more on government funding and have less room to increase tuition and fees when faced with financial difficulties; thus, they are more likely to seek other funding, including foundation grants. This can be seen from the negative association between the percentage of government funding in an institution's total revenue and the total dollar amount of grants awarded. On the other hand, institutional characteristics that indicate high productivity, including graduation rates, dollars spent on research per faculty, and large university, are positively associated with all three measures of grant results - the probability of 
Table 11 Difference-in-differences estimates of effects of Koch funding on HBCU research productivity

\begin{tabular}{|c|c|c|c|c|c|c|}
\hline & \multicolumn{3}{|c|}{$\begin{array}{l}\text { Dependent variable: annual average number of } \\
\text { publications per faculty }\end{array}$} & \multicolumn{3}{|c|}{$\begin{array}{l}\text { Dependent variable: annual average number of } \\
\text { publications }\end{array}$} \\
\hline & OLS (1) & OLS (2) & OLS (3) & OLS (4) & OLS (5) & OLS (6) \\
\hline \multirow[t]{2}{*}{ Received Koch grant $*$ Post-funding period } & 0.0052 & & 0.0052 & 0.7574 & & 0.7853 \\
\hline & $(0.0039)$ & & $(0.0041)$ & $(0.6283)$ & & $(0.6696)$ \\
\hline \multirow[t]{2}{*}{ Post-funding period (after year of 2010) } & $0.0029 * * *$ & & & $0.5892 * * *$ & & \\
\hline & $(0.0008)$ & & & $(0.1564)$ & & \\
\hline \multirow[t]{2}{*}{ Received Koch grant } & & 0.0052 & & & 0.7853 & \\
\hline & & $(0.0041)$ & & & $(0.6696)$ & \\
\hline \multirow[t]{2}{*}{ Economics degrees } & $-0.0061 * * *$ & $-0.0063 * * *$ & $-0.0063 * * *$ & 0.0450 & 0.0360 & 0.0360 \\
\hline & $(0.0011)$ & $(0.0010)$ & $(0.0010)$ & $(0.1949)$ & $(0.1799)$ & $(0.1799)$ \\
\hline \multirow[t]{2}{*}{ Public HBCU } & $0.0093 * * *$ & $0.0092 * * *$ & $0.0092 * * *$ & $0.6601 * * *$ & $0.6565 * * *$ & $0.6565 * * *$ \\
\hline & $(0.0010)$ & $(0.0010)$ & $(0.0010)$ & $(0.2167)$ & $(0.2060)$ & $(0.2060)$ \\
\hline \multirow[t]{2}{*}{ Graduation rate } & -0.0000 & -0.0000 & -0.0000 & -0.0008 & 0.0004 & 0.0004 \\
\hline & $(0.0000)$ & $(0.0000)$ & $(0.0000)$ & $(0.0023)$ & $(0.0024)$ & $(0.0024)$ \\
\hline \multirow[t]{2}{*}{ Small HBCU_2016 } & $-0.0050 * *$ & $-0.0054 * *$ & $-0.0054 * *$ & $-1.0525 * *$ & $-1.1098 * *$ & $-1.1098 * *$ \\
\hline & $(0.0024)$ & $(0.0022)$ & $(0.0022)$ & $(0.5168)$ & $(0.4916)$ & $(0.4916)$ \\
\hline \multirow[t]{2}{*}{ High share of black faculty } & -0.0006 & -0.0005 & -0.0005 & -0.2318 & -0.2161 & -0.2161 \\
\hline & $(0.0016)$ & $(0.0016)$ & $(0.0016)$ & $(0.3031)$ & $(0.3094)$ & $(0.3094)$ \\
\hline \multirow[t]{2}{*}{ Constant } & $0.0068 * * *$ & $0.0057 * *$ & $0.0061 * *$ & $1.4197 * * *$ & $1.3930 * * *$ & $1.3691 * * *$ \\
\hline & $(0.0026)$ & $(0.0024)$ & $(0.0024)$ & $(0.4900)$ & $(0.4541)$ & $(0.4498)$ \\
\hline Year fixed effects & No & Yes & Yes & No & Yes & Yes \\
\hline Institutional fixed effects & Yes & Yes & Yes & Yes & Yes & Yes \\
\hline State fixed effects & Yes & Yes & Yes & Yes & Yes & Yes \\
\hline Observations & 943 & 943 & 943 & 1174 & 1174 & 1174 \\
\hline Adjusted $R^{2}$ & 0.345 & 0.353 & 0.353 & 0.619 & 0.623 & 0.623 \\
\hline
\end{tabular}

Robust standard errors in parentheses

$* * * p<0.01, * * p<0.05, * p<0.1$

receiving a grant, the total dollar amount of grants awarded, and the average amount per grant.

The only instance where we find positive impacts of Koch funding on HBCU productivity is when we measure productivity by citations. Conditional on having any citations, HBCUs that have ever received a grant from the Charles Koch Foundation have higher citations per faculty member compared with non-funded HBCUs in the post-funding period after 2010. Such results show that the Charles Koch Foundation achieves its goals in supporting research that does not sit on a shelf, but is "read, scrutinized, debated, and consulted." Unfortunately, these results vanish when we use the Poisson model vs. the OLS and GLM methods. Moreover, one can speculate that even these positive but barely significant impacts on citations may reflect the national prestige and largess of the Koch Foundation and its ability to promote and induce citations for the limited number of publications arising from grants it funds.

These findings partially validate concerns that the Charles Koch Foundation targets vulnerable and controllable colleges and universities and does not enhance the research productivity of those institutions. The stated purpose of the foundation in funding research at colleges and universities is to produce research that could have an impact. When we examine whether grants from the foundation increase research productivity, for the sub-group of all HBCUs and in the subfield of economics, we fail to find consistent and robust evidence of research productivity improvements. This suggests that other foundation goals-e.g., influencing ideological perspectives - dominate the decisions to fund HBCUs.

This paper has several limitations. First, we have not modeled or tested the plausible hypothesis that Koch's funding of HBCUs is driven by its desire to transform the ideological landscape within HBCUs. Such an exercise is beyond the scope of this paper.

Second, the findings reveal associations and do not establish causal claims. The associations revealed in this paper could be the result of causal paths in either or both directions. For example, while we could argue that the Charles Koch Foundation tends to target vulnerable and controllable institutions, one could also argue that Koch has provided financial help to institutions in the greatest of difficulty. The list of 
funded HBCUs includes such struggling colleges as Claflin University and Stillman College. Missing from the list of HBCUs receiving Koch grants are Morgan State University - one of the top producers of black PhDs in the country - as well as Howard University, Spelman College, and Morehouse College - top black schools with a legacy of producing high-quality graduates and faculty who publish in top economics journals.

Another limitation of the paper is that we might not have adequately accounted for the selection process, which is the foundation of the Koch Foundation's funding goals and strategies and which may explain its funding of HBCUs as well as white institutions. They likely select TWI grantees based on their productivity. We are unable to control for prior research productivity when estimating the probability of receiving grants from the Charles Koch Foundation. However, we can control for pre-funding research productivity for the subsample of HBCUs and have modeled this as an event study. The event study and DID results mirror the OLS and 2-step GLM results.

A final limitation of this paper is that given the grant process where colleges and universities submit proposals and the Charles Koch Foundation reviews those proposals and approves grants, the selection could happen on both sides. The observed differences in grant results between HBCUs and non-HBCUs could be attributed to screening and selection by the Charles Koch Foundation. It is also possible that HBCUs are less likely to apply for the Charles Koch Foundation grants.

This paper provides a glimpse into the broader policy area of how foundations make funding decisions that affect the wellbeing of HBCUs. The paper indirectly alludes to the problem of funding that is conditioned upon possible strings attached. Without suitable measures of the content of the sponsored research, this paper cannot address the issue of whether the Charles Koch Foundation is buying brains from colleges and universities to support its ideological stance and public agenda.

Nevertheless, this paper contributes to the current literature by bringing empirical evidence from a case of a controversial foundation donor on research in institutions of higher education and calling for future research on the impacts of foundation giving on research productivity.

Acknowledgments We thank Diana Vega Vega for providing research assistance with data collection and Julia Blount for editing assistance. We also thank participants in the 89th Southern Economics Associations Annual Meeting for helpful comments.

Funding Information This study received funding from the Roy Wilkins Center for Human Relations and Social Justice and the Hutchinson Fund.

\footnotetext{
${ }^{9}$ We note that the Koch Foundation made a grant to Gregory Price, formerly at Morehouse College, to examine the relationship between entrepreneurship and crime, but this grant was made after the time frame of our sample.
}

\section{Compliance with Ethical Standards}

Conflict of Interest The authors declare that they have no conflicts of interest.

\section{Appendix 1}

Table 12 List of grants from the Charles Koch Foundation to HBCUs

\begin{tabular}{lll}
\hline Year & HBCU & Grant amount \\
\hline 2010 & Stillman College & $\$ 7500$ \\
2010 & Delaware State University & $\$ 7250$ \\
2011 & Delaware State University & $\$ 8172$ \\
2011 & Fayetteville State University & $\$ 7000$ \\
2012 & Albany State University & $\$ 11,000$ \\
2012 & Winston-Salem State University & $\$ 8600$ \\
2013 & Albany State University & $\$ 15,000$ \\
2013 & Fayetteville State University & $\$ 20,000$ \\
2013 & Winston-Salem State University & $\$ 5000$ \\
2014 & Winston-Salem State University & $\$ 11,800$ \\
2014 & Claflin University & $\$ 6500$ \\
2014 & Hampton University & $\$ 8000$ \\
2015 & Tuskegee University & $\$ 535$ \\
2015 & Winston-Salem State University & $\$ 11,800$ \\
2016 & Albany State University & $\$ 32,000$ \\
2016 & Southern University at New Orleans & $\$ 10,000$ \\
2016 & Claflin University & $\$ 12,400$ \\
\hline
\end{tabular}

\section{Appendix 2}

Table 13 List of the top 30 economics journals
1. Quarterly Journal of Finance
2. Econometrica
3. Journal of Finance
4. Journal of Political Economy
5. Review of Financial Studies
6. Journal of Financial Economics
7. American Economic Review
8. Review of Economic Studies
9. Journal of Labor Economics
10. Journal of Marketing
11. Annual Review of Economics
12. Journal of Marketing Research
13. Marketing Science
14. Journal of Human Resources 
Table 13 (continued)

15. Journal of Economics Perspectives

16. Journal of Economic Literature

17. Journal of Monetary Economics

18. Review of Economics and Statistics

19. Journal of Accounting Research

20. Journal of Accounting and Economics

21. Brookings Papers on Economic Activity

22. Journal of Consumer Research

23. Journal of Economic Growth

24. Journal of International Business Studies

25. Journal of Econometrics

26. Economic Journal

27. Quantitative Economics

28. Journal of the Academy of Marketing Science

29. Annual Review of Financial Economics

30. Journal of International Economics

\section{Appendix 3}

Table 14 First step estimates of effects of Koch funding on the number of economics publications per faculty member, year: 2010-2016

\begin{tabular}{|c|c|c|c|}
\hline & Two step (1) logit & Two step (2) logit & Two step (3) logit \\
\hline \multirow[t]{2}{*}{ Public HBCU } & 0.2175 & 0.2083 & 0.2073 \\
\hline & $(0.6067)$ & $(0.6062)$ & $(0.6063)$ \\
\hline \multirow[t]{2}{*}{ Economics degrees } & -0.1867 & -0.2007 & -0.2024 \\
\hline & $(0.9188)$ & $(0.9212)$ & $(0.9214)$ \\
\hline \multirow[t]{2}{*}{ Publication per faculty_2009 } & $73.6918 * *$ & $73.7055^{* *}$ & $73.7408 * *$ \\
\hline & $(34.7732)$ & $(34.8703)$ & $(34.8426)$ \\
\hline \multirow[t]{2}{*}{ Black faculty share_2016 } & -2.4958 & -2.4929 & -2.4987 \\
\hline & $(2.0220)$ & $(2.0223)$ & $(2.0230)$ \\
\hline \multirow[t]{2}{*}{ Small HBCU_2016 } & -0.8956 & -0.8908 & -0.8903 \\
\hline & $(1.0578)$ & $(1.0577)$ & $(1.0581)$ \\
\hline \multirow[t]{2}{*}{ Graduation rate_2016 } & $4.4392 *$ & $4.5206^{*}$ & $4.5363 *$ \\
\hline & $(2.5081)$ & $(2.5039)$ & $(2.5003)$ \\
\hline \multirow[t]{2}{*}{ Received Koch grant } & $1.3036^{* *}$ & & \\
\hline & $(0.6163)$ & & \\
\hline \multirow[t]{2}{*}{ Ln (total amount Koch grant) } & & $0.1410 *$ & \\
\hline & & $(0.0754)$ & \\
\hline \multirow[t]{2}{*}{ Ln (average amount per Koch grant) } & & & 0.1411 \\
\hline & & & $(0.1132)$ \\
\hline \multirow[t]{2}{*}{ Constant } & -0.2106 & -0.2299 & -0.2310 \\
\hline & $(2.0713)$ & $(2.0694)$ & $(2.0708)$ \\
\hline State fixed effects & Yes & Yes & Yes \\
\hline Observations & 101 & 101 & 101 \\
\hline First step likelihood & -40.31 & -40.39 & -40.4 \\
\hline Chi squared & 22.97 & 22.11 & 22.12 \\
\hline
\end{tabular}

Standard errors in parentheses and clustered at the state level

$* * * p<0.01, * * p<0.05, * p<0.1$ 
Table 15 First step estimates of effects of Koch funding on the economics publication citations per faculty member, year 2010 2016

\begin{tabular}{|c|c|c|c|}
\hline & Two step (1) logit & Two step (2) logit & Two step (3) logit \\
\hline \multirow[t]{2}{*}{ Public HBCU } & 0.3695 & 0.3582 & 0.3580 \\
\hline & $(0.6182)$ & $(0.6167)$ & $(0.6167)$ \\
\hline \multirow[t]{2}{*}{ Economics degrees } & -1.9026 & -1.9256 & -1.9459 \\
\hline & $(1.3660)$ & $(1.3595)$ & $(1.3590)$ \\
\hline \multirow[t]{2}{*}{ Publication per faculty_2009 } & $5.4784 * * *$ & $5.4825^{* * *}$ & $5.5010^{* * *}$ \\
\hline & $(1.3653)$ & $(1.3666)$ & $(1.3712)$ \\
\hline \multirow[t]{2}{*}{ Black faculty share_2016 } & -2.1836 & -2.1821 & -2.1900 \\
\hline & $(2.1527)$ & $(2.1502)$ & $(2.1534)$ \\
\hline \multirow[t]{2}{*}{ Small HBCU_2016 } & -1.3495 & -1.3449 & -1.3418 \\
\hline & $(1.0074)$ & $(1.0075)$ & $(1.0070)$ \\
\hline \multirow[t]{2}{*}{ Graduation rate_2016 } & $4.2917^{*}$ & $4.3568^{*}$ & $4.4003 *$ \\
\hline & $(2.5441)$ & $(2.5419)$ & $(2.5324)$ \\
\hline \multirow[t]{2}{*}{ Received Koch grant } & 0.7292 & & \\
\hline & $(0.9606)$ & & \\
\hline \multirow[t]{2}{*}{ Ln (total amount Koch grant) } & & 0.0719 & \\
\hline & & $(0.1027)$ & \\
\hline \multirow[t]{2}{*}{ Ln (average amount per Koch grant) } & & & 0.0682 \\
\hline & & & $(0.1091)$ \\
\hline \multirow[t]{2}{*}{ Constant } & 0.0190 & 0.0074 & -0.0008 \\
\hline & $(2.2418)$ & $(2.2381)$ & $(2.2392)$ \\
\hline State fixed effects & Yes & Yes & Yes \\
\hline Observations & 101 & 101 & 101 \\
\hline First step likelihood & -42.66 & -42.71 & -42.74 \\
\hline Chi squared & 31.32 & 31.43 & 31.52 \\
\hline
\end{tabular}

Standard errors in parentheses and clustered at the state level

$* * * p<0.01, * * p<0.05, * p<0.1$

\section{Appendix 4}

Table 16 Variable definitions for difference-in-difference estimates

\begin{tabular}{ll}
\hline Variable & Description \\
\hline Received Koch grant & Received grants from Charles Koch between 2010 and 2016 \\
Post-funding period & Year of 2010 and later \\
Economics degrees & Offer a bachelor's degree in economics major \\
Public HBCU & Public historical black colleges or universities \\
Graduation rate & Annual average graduation rate \\
Small HBCU_2016 & Average student enrollment under 5000 \\
High share of black faculty & The average share of black faculty members is more than 50\% \\
\hline
\end{tabular}


Open Access This article is licensed under a Creative Commons Attribution 4.0 International License, which permits use, sharing, adaptation, distribution and reproduction in any medium or format, as long as you give appropriate credit to the original author(s) and the source, provide a link to the Creative Commons licence, and indicate if changes were made. The images or other third party material in this article are included in the article's Creative Commons licence, unless indicated otherwise in a credit line to the material. If material is not included in the article's Creative Commons licence and your intended use is not permitted by statutory regulation or exceeds the permitted use, you will need to obtain permission directly from the copyright holder. To view a copy of this licence, visit http://creativecommons.org/licenses/by/4.0/.

\section{References}

About us. (n.d.). https://www.charleskochfoundation.org/about-us/. Accessed 23 July 2020.

$\$ 5$ million gift from Charles Koch Foundation will support department of economics. The Campaign for George Mason University. (2018). http://fasterfarther.gmu.edu/news/5-million-gift-from-charles-kochfoundation-for-economics/. Accessed 23 July 2020.

Agesa J, Granger M, Price GN. Economics research at historically black colleges and universities: rankings and effects on the supply of black economists. Rev Black Polit Econ. 1998;25(4):41-53.

Agesa J, Granger M, Price GN. Economics faculty research at teaching institutions: are historically black colleges different? South Econ J. 2000:427-47.

Agesa J, Granger M, Price GN. Swimming upstream?: the relative research productivity of economists at black colleges. Rev Black Poli Econ. 2001;29(3):71-92.

Agesa J, Granger M, Price GN. The research productivity of black economists: ranking by individuals and doctoral alma mater. Rev Black Poli Econ. 2002;30(2):7-24.

Agesa J, Granger M, Price GN. The research productivity of black economists: a rejoinder. Rev Black Poli Econ. 2005;33(3):51-63.

Anderson N. Charles Koch teams with black colleges on education and criminal justice research. Wash Post. 2017; https://www. washingtonpost.com/local/education/charles-koch-teams-withblack-colleges-on-education-and-criminal-justice-research/2017/ 01/11/ab8a8d02-d838-11e6-9f9f-5cdb4b7f8dd7_story.html? noredirect=on\&utm_term=.a869a5756e9e. Accessed 23 July 2020.

Betsey CL. Faculty research productivity: institutional and personal determinants of faculty publications. Rev Black Poli Econ. 2007;34(12):53-85.

Boyce BA. Philanthropic funding in higher education: carrot and/or stick. Quest. 2013;65(3):255-65.

Cho S. Center for the history of political economy receives $\$ 5$ million from Koch foundation to expand faculty. Chronicle. 2018; https:// www.dukechronicle.com/article/2018/09/center-for-the-history-ofpolitical-economy-receives-5-million-to-expand-faculty.

Dougal C, Gao P, Mayew WJ, Parsons CA. What's in a (school) name? Racial discrimination in higher education bond markets. J Financ Econ. 2019;134(3):570-90.

Dow WH, Norton EC. Choosing between and interpreting the Heckit and two-part models for corner solutions. Health Serv Outcome Res Methodol. 2003;4(1):5-18.

Dundar H, Lewis DR. Determinants of research productivity in higher education. Res High Educ. 1998;39(6):607-31.

Fichtenbaum R. Here's why politically motivated philanthropy is dangerous. Chron High Educ. 2018; https://www.chronicle.com/article/Here-sWhy-Politically $/ 243389$ ?cid $=$ cr\&utm_source $=$ cr\&utm_medium $=$ en\&elqTrackId=8d56f8f28774419c97721 f8cdbdf799f\&elq= a73ff99a 1 f154dc1bbd21f7d6de567cc\&elqaid=19033\&elqat= 1\&elqCampaignId $=8615$.

Fink R. The structure of social change. 2012. https://www.ia601304.us. archive.org/10/items/TheStructureOfSocialChangeLiberty GuideRichardFinkKoch/The\%20Structure\%20of\%20Social\% 20Change\%20_\%20Liberty\%20Guide\%20_\%20Richard\% 20Fink\%20_\%20Koch.pdf. Accessed 23 July 2020.

Frondel M, Vance CJ. Interpreting the outcomes of two-part models. Appl Econ Lett. 2012;19(10):987-92.

Garfield E. Journal citation reports; a Bibliometric Analysis of References Processed for the 1974 Science Citation Index. Science Citation Index 1975 (Vol. 9). Philadelphia: Institute for Scientific Information Philadelphia; 1976.

Gasman M. Historically black colleges and universities in a time of economic crisis. Academe. 2009;95(6):26-8.

Gasman M. Give the money back: Inside Higher Ed; 2014. https://www. insidehighered.com/views/2014/06/12/essay-urges-uncf-rejectmajor-gift-koch-brothers. Accessed 23 July 2020.

Gasman M, Baez B, Drezner ND, Sedgwick KV, Tudico C, Schmid JM. Historically Black colleges and universities: recent trends. Academe. 2007;93(1):69-77.

Hardin J. All college giving should be held to the same standard. Chron High Educ. 2018; https://www.chronicle.com/article/All-CollegeGiving-Should-Be/243388?cid=cr\&utm_source $=$ cr\&utm_medium $=$ en\&elqTrackId $=7 \mathrm{e} 05 \mathrm{a} 4296 \mathrm{~d} 86446998 \mathrm{c} 5 \mathrm{~d} 5358 \mathrm{fb} 571 \mathrm{bf} \& \mathrm{elq}=$ a73ff99a1f154dc1bbd21f7d6de567cc\&elqaid=19033\&elqat $=$ 1\&elqCampaignId $=8615$.

Harris GT. Research output in Australian university economics departments: an update for 1984-88'. Aust Econ Pap. 1990;29(55):24959.

Kotch A. How Charles Koch is helping neo-confederates teach college students: The Nation; 2018. https:/www.thenation.com/article/ how-charles-koch-is-helping-neo-confederates-teach-collegestudents/. Accessed 23 July 2020.

Kothari SP, Warner JB. Econometrics of event studies. In: Handbook of empirical corporate finance: Elsevier; 2007. p. 3-36.

Kumashiro KK, Miller KS, Bellamy R, Melehy H, Priesmeyer M, Goodwin SA. When billionaires become educational experts. Academe. 2012;98(3):10-6.

List of supported colleges. (2018). https://www.charleskochfoundation. org/our-giving-and-support/higher-education/list-of-supportedcolleges/. Accessed 15 Nov 2018.

MacKinlay AC. Event studies in economics and finance. J Econ Lit. 1997;35(1):13-39.

Mock B. Why are the Kochs giving $\$ 25$ million to poor black college students? Grist; 2014. https://www.grist.org/politics/why-are-thekochs-giving-25-million-to-poor-black-college-students/. Accessed 23 July 2020.

Morse L, Sakano R, Price GN. Black public colleges and universities as projects: how do they rank relative to white public colleges and universities? Rev Black Poli Econ. 1996;24(4):65-79.

Murray F. Evaluating the role of science philanthropy in American research universities. Innov Policy Econ. 2013;13(1):23-60.

Myers SL Jr. The production of Black Ph. D.'s in economics at Harvard University, 1905-1955. Rev Black Poli Econ. 2017;44(1-2):167201.

Ortega A, Swinton OH. Business cycles and HBCU appropriations. J Econ Race Policy. 2018;1(2-3):176-95.

Price GN. Would increased National Science Foundation research support to economists at historically black college and universities increase their research productivity? Rev Black Poli Econ. 2007;34(1-2):87-109.

Price GN, Spriggs W, Swinton OH. The relative returns to graduating from a historically Black college/university: propensity score matching estimates from the national survey of Black Americans. Rev Black Poli Econ. 2011;38(2):103-30. 
Roosevelt M. \$5 million to California university from billionaire Charles Koch sparks an uproar: The Mercury News; 2018. https://www. mercurynews.com/2018/06/11/5-million-to-california-universityfrom-billionaire-charles-koch-sparks-an-uproar/. Accessed 23 July 2020.

Sav GT. Funding historically black colleges and universities: progress toward equality? J Educ Financ. 2010;35(3):295-307.

Texas A\&M Foundation Staff. Charles Koch Foundation grant supports economic policy research: Texas A\&M Today; 2017. https://www. today.tamu.edu/2017/09/20/charles-koch-foundation-grantsupports-economic-policy-research/. Accessed 23 July 2020.

The higher education grant giving principles. (n.d.) https://www. charleskochfoundation.org/our-giving-and-support/our-givingstandards/. Accessed 23 July 2020.

Thurgood Marshall College Fund launches new center with support of \$26 million gift from Charles Koch Foundation and Koch
Industries. (2017). https://www.tmcf.org/tmcf-in-the-news/ thurgood-marshall-college-fund-launches-new-center-with-supportof-26-million-gift-from-charles-koch-foundation-and-kochindustries/10939. Accessed 23 July 2020.

Toldson IA. The funding gap between historically black colleges and universities and traditionally white institutions needs to be addressed*(editor's commentary). J Negro Educ. 2016;85(2):97100.

Why George Mason's agreements with the Koch Foundation raised red flags. Chronicle of Higher Education. (2018). https://www. chronicle.com/article/Why-George-Mason-s/243314. Accessed 23 July 2020.

Publisher's Note Springer Nature remains neutral with regard to jurisdictional claims in published maps and institutional affiliations. 